\title{
Cultivating biomass locally or importing it? LCA of biomass provision scenarios for cleaner electricity production in a small tropical island
}

\author{
Chary Killian ${ }^{1,2}$, Aubin Joël ${ }^{3,4}$, Guindé Loïc ${ }^{1}$, Sierra Jorge ${ }^{1}$, Blazy Jean-Marc ${ }^{1,{ }^{*}}$
}

${ }^{1}$ INRA, UR1321 ASTRO Agrosystèmes Tropicaux, F-97170 Petit-Bourg (Guadeloupe), France

2 Ifremer, UMR 9190 MARBEC (IRD - Ifremer - Univ. Montpellier - CNRS), Station Ifremer, Route de Maguelone, F-34250 Palavas-les-Flots, France

${ }^{3}$ INRA, UMR 1069 Sol Agro et Hydrosystème Spatialisation, F-35000 Rennes, France

${ }^{4}$ Agrocampus Ouest, F-35000 Rennes, France

*Corresponding author : Jean-Marc Blazy, email address : Jean-Marc.Blazy@inra.fr

\begin{abstract}
:
Biomass is a promising renewable alternative to decarbonize and to secure energy production on small islands, as most insular power generation systems rely heavily on imported fossil fuels. Feedstock procurement is a key aspect of bioenergy chain sustainability, and local resources as well as imported biomass can be considered if the electricity generated presents environmental benefits. We used Life Cycle Assessment (LCA) to evaluate the environmental impacts of $1 \mathrm{kWh}$ of electricity produced in Guadeloupe from the combustion of locally grown energy cane and imported wood pellets. The energy cane agricultural supply was simulated using a bio-economic model to elaborate and analyze five scenarios involving different biomass mixes and geographical areas of production. Our results show that electricity produced from energy cane reduced the impacts of ABIOTIC DEPLETION, ACIDIFICATION and PHOTOCHEMICAL OXIDATION by $29 \%$ compared with pellet-based electricity. The environmental impacts of the energy cane cultivation stage varied by a factor of 1.5-3.7 among regional areas of cultivation because of differences in yields, soil emissions and land conversion for energy crop farming. The substitution of $5 \%$ of fossil energy by biomass in the island electricity mix can reduce GLOBAL WARMING and ABIOTIC DEPLETION impact by $4.5 \%$. However, this change requires 3.5 to 5.2 times higher LAND OCCUPATION per unit of energy produced. Given the limited land availability on small islands, this latter point confirms that the combination of locally grown energy crops with imported biomass will be a suitable strategy to develop sustainable bioenergy for small islands.
\end{abstract}




\section{Highlights}

- Locally grown energy cane and imported wood pellets were tested for biomass provision. Energy cane agricultural supply was simulated at field scale with a bioeconomic model. Energy cane performs better, but impacts vary spatially in the area of production. Importing a portion of wood pellets seems necessary to reduce pressure on the land. Substituting $5 \%$ of fossil energy by biomass in the energy mix can reduce GLOBAL WARMING by $4.5 \%$.

Keywords : LCA, Electricity, Energy cane, Wood pellet, Islands, Saccharum sp. 


\section{Introduction}

Biomass is a promising renewable alternative to decarbonize and to secure energy production in small islands [1,2], as most insular power generation systems rely heavily on imported fossil fuels, which are costly and responsible for greenhouse gas (GHG) emissions $[3,4]$. The isolation from continental networks leads to the need for stable and autonomous energetic systems. Therefore, a higher level of biomass-based energy can enhance the reliability of the power production, as biomass provides continuous energy, whereas intermittent resources such as sun or wind depend on meteorological conditions [2]. Several other factors motivate the exploitation of biomass, such as job creation for resident workers and rural economic diversification [5], as food production is not always highly competitive in small island territories compared to imported foodstuffs.

In Guadeloupe, a small tropical archipelago in the Caribbean, biomass has to play a key role in reaching the ambitious objective of $50 \%$ renewable energy in the final electric mix by 2020 , as declared by regional energy policy [6]. As forest biomass is limited and located in the volcanic area, it is not easily exploitable. Therefore bioenergy feedstock is more likely to come from agricultural sources. Sugarcane (Saccharum sp.) is recognized as an excellent energy feedstock because of its high photosynthetic efficiency, its larger productivity than most other crops under tropical conditions and its high primary energy content per mass unit of cane [7-9]. In the sugar value chain, sugarcane provides a range of co-products such as bagasse and molasses that can be used as energy carriers and converted into biofuels, heat or electricity [8]. Bagasse, the fibrous residue after juice extraction, is used as a combustible in thermal plants and has generated $4 \%$ of the annual electricity production (1734 GWh) of Guadeloupe in 2014. As land availability is naturally limited on small tropical islands, the potential contribution of biomass to the electric mix can be further increased with "energy cane", a dedicated crop grown from hybrid cultivars of sugarcane selected for high biomass production, high fiber content and low sucrose concentration [10,11]. Unlike conventional perennial 
sugarcane, these Saccharum cultivars can be used as a multipurpose energy crop (e.g. for the production of biofuels, electricity or gas) [8]. Among the fibrous plants, energy cane has one of the biggest potential for biomass production. Results from several breeding programs have indeed shown the high biomass potential of energy cane over other biomass crops like sorghum, elephant grass and eucalyptus [11-14].

Because feedstock provision is a key aspect of the viability and sustainability of bioenergy chains [15-17], three options are considered for electricity production in Guadeloupe with biomass power plant: 1) the local production of energy cane and 2) the import of wood pellets and 3) a mix of locally grown and imported biomass. A multibiomass supply chain has the advantage of ensuring a continuous feedstock supply, particularly as extreme climatic events might affect biomass growth and harvest. Therefore, multibiomass systems reduce economic risks for the industrial investors $[18,19]$. The import of wood pellets is becoming more common in bioenergy development, as this heating fuel shows interesting characteristics such as low humidity content, high density, practical handling and stable characteristics in long-term storage [20,21]. However, to be a sustainable energy option, energy cane and wood pellets should be less energy intensive and environmentally harmful than current energy sources [22]. Therefore, a comprehensive environmental assessment is crucial before investment decisions are made. For this purpose, Life Cycle Assessment (LCA) is an appropriate method.

LCA has been applied to the analysis of many bioenergy systems. Previous LCA analyses of sugarcane systems were oriented toward the use of sugar-coproducts for energy purposes in sugar industries [23-27] and, to a lesser extent, to dedicated sugarcane energy crops used for ethanol production from cane juice and electricity cogeneration from bagasse [28-30]. Only one environmental assessment of electricity generation from dedicated energy cane crop using LCA has been reported on La Reunion Island [31]. Many studies confirmed that bagasse electricity has produced reductions in GLOBAL WARMING and Non-renewable energy use when substituted for 
hard coal in boilers $[24,25,27]$. Great uncertainty has been observed in the results of LCA of valorization of sugarcane products, as in other bioenergy systems. The uncertainty is mainly due to 1) variability in cultivation stage due to regional conditions (soil, climate), agronomic parameters (yield, nitrogen fertilizer application) and emissions modeling (e.g., nitrogen (N) emissions from soils and land use change) and 2) the choice of methodological approach for allocating impacts to the multiple outputs $[15-17,32,33]$. The environmental sustainability of wood pellets as a domestic or imported resource has also been questioned in number of LCA case studies [34-39]. These studies report that using wood pellets for energy has environmental benefits over fossil fuels even with long range transportation, as this latter causes modest GHG emissions compared to those of fossil fuel combustion. However, the environmental performance is expected to be lower than with locally produced biomass, and therefore a comparison with the environmental profile of local resources is necessary to find the best mix option of these two sources of biomass.

The goal of this paper was to assess through LCA the environmental impacts of electricity generation from the combustion of locally grown energy cane and imported wood pellets in a tropical island context (Guadeloupe). Five scenarios of biomass provision are compared to assess the environmental performances of electricity according to 1) the composition of the biomass mix and 2) the localization of biomass production areas. This latter is modeled using a regional bio-economic model that considers soil and farm diversity $[40,41]$ and simulates the adoption of energy cane by farmers as a function of its profitability, farm constraints and policy context. In the LCA, a deeper focus on the impacts of the cultivation stage is then applied. Finally, we examined the environmental benefits and drawbacks of biomass electricity penetration within the energy mix and draw conclusions regarding the best options for developing sustainable biomass-based energy systems in the context of small tropical islands. 


\section{Methods}

\subsection{A generic approach to assess ex ante biomass benefit}

We developed a simple and generic approach to assess the environmental benefit of developing energy cane based bioenergy in any territory. The approach, summarized in Fig. 1, is based on the coupling of two models and is structured as follow: (1) Investigate the potential geo-localization production of energy cane using the bio-economic model MOSAICA (described in 2.4.1) that simulates agricultural land use at the territory scale (Guadeloupe in our case); (2) Perform the LCA of biomass (energy cane and pellet in our case) and bioenergy production according to several scenarios of interest; (c) Include the biomass energy carriers LCA within the energy mix LCA of the considered territory (Guadeloupe in our case).

< Insert Figure 1 about here >

\subsection{LCA methodology}

LCA is a methodological framework used to estimate the emissions and consumption of resources to elaborate a product or a service such as energy production, from manufacture to use and associated waste management (from "cradle to grave") [42]. LCA procedures are built in 4 steps: (1) goal, scope and system definition, (2) life cycle inventories (LCI) of emissions and resource use, (3) environmental impact assessment and (4) interpretation. In our study, Life Cycle Impact Assessment (LCIA) was elaborated using impact categories commonly applied in LCA studies of bioenergy systems, such as ABIOTIC DEPLETION of fossil fuels (MJ fossils), ACIDIFICATION ( $\mathrm{SO}_{2}$ eq.), EUTROPHICATION ( $\mathrm{PO}_{4}{ }^{3-}$ eq. $)$, GLOBAL WARMING $\left(\mathrm{CO}_{2}\right.$ eq. $)$, PHOTOCHEMICAL OXIDATION $\left(\mathrm{C}_{2} \mathrm{H}_{4}\right.$ eq. $)$ using the CML IA baseline method (V3.02) [42] and LAND OCCUPATION (agricultural + urban in $\mathrm{m}^{2}$.year) from the ReCiPe Midpoint (E) method (V1.12) [43]. The impact categories were calculated using the SimaPro 8.1 software by PRé Consultants. 


\subsection{Goal, scope and system boundaries}

The intended application of this paper is to produce an ex-ante assessment of the environmental performances of a new renewable energy source and to compare it with existing exploited fossil resources in Guadeloupe. Our main goal was to assess the environmental performances of electricity generation from a combined use of energy cane locally cropped with imported pellet and to compare the environmental efficiency of different options of biomass mix. We also aimed to examine the benefits and drawbacks of this bioenergy penetration within the energy mix. Thus, $1 \mathrm{kWh}$ of electricity produced was set as principal functional unit $\left(\mathrm{FU}_{1}\right)$. In order to take into account the variability in environmental emissions due to spatial heterogeneity of fields in a tropical insular context (Guadeloupe), the environmental impacts of energy cane cultivation stage were also assessed for $215 \mathrm{kt}\left(\mathrm{FU}_{2}\right)$ of biomass harvested, which corresponds to the annual feedstock requirement for a $12 \mathrm{MWe}$ power plant supplied only with energy cane biomass. The choice of $12 \mathrm{MWe}$ as size of biomass power plant, corresponds to the wish of local policy makers as a first step in energetic transition. It corresponds to $5 \%$ of the need of the 400000 inhabitants of Guadeloupe.

The LCA of the bioenergy system is conducted cradle to plant gate, comprising feedstock production, transport and conversion stages for the two biomass resources, as depicted in Fig. 2 . Transmission and use of the electricity is not included in the system. Similarly, impacts associated with infrastructure as well as transport of persons were excluded from the analysis. In the following subsections, we describe the case study area and detail each step of the life cycle and the corresponding hypothesis.

< Insert Figure 2 about here >

\subsubsection{Data collection}

All necessary inventory data analyzed in this work were collected in Guadeloupe during the research project. The sugarcane crop management system and industry are well-established in Guadeloupe because sugarcane is the main crop of the island. Thus, the energy cane supply chain was designed 
following the actual model of sugarcane industry and most of inventory data was based on it. Primary data specific to energy cane were obtained from experimental agronomic trials, laboratory experiments, soil and climate database and a survey of farmers involved in sugarcane in Guadeloupe for assessing their perceptions of this new agro-industry. All data regarding power plant technologies, scale and performance were obtained from the expertise and industrial trials of the energy company involved in the research project. These data were complemented with background data from the Life-Cycle Inventory (LCI) Ecoinvent Database 2.2 [44] and French LCI database Agribalyse v1.1 [45]. These data are detailed below.

\subsubsection{Case study area}

The French archipelago of Guadeloupe is located in the Lesser Antilles and is composed of two main islands (Fig. 3): Grande-Terre in the north of the archipelago and Basse-Terre in the South, with a range of rainfall conditions and great soil diversity. The major soil types occurring in the flat lands of Grande-Terre $\left(587 \mathrm{~km}^{2}\right)$ are calcisols and vertisols, whereas the volcanic island of Basse-Terre (848 $\mathrm{km}^{2}$ ) includes andisols, nitisols, ferralsols and vertic soils. In the southern island (Basse-Terre) the average precipitation ranges from 1600 to $4000 \mathrm{~mm}$ depending on the altitude, and the mean annual temperature is $25.5^{\circ} \mathrm{C}$. The climate is drier on the northern island (Grande-Terre), with a mean annual temperature of $27^{\circ} \mathrm{C}$ and average precipitation of approximately $1100 \mathrm{~mm}$ [46].

< Insert Figure 3 about here >

\subsubsection{Energy cane cultivation}

The crop management system of sugarcane including planting, fertilization, harvest and transport is well-established, particularly in Guadeloupe where sugarcane is the main crop. As energy cane is a cultivar of sugarcane, the crop management system is very close to the one of conventional 
sugarcane $[12,14]$. The cultivation stage includes therefore the production and transport of agricultural inputs such as cuttings (cane stalk use to re-grow), NPK (9/19/28 at $600 \mathrm{~kg} / \mathrm{ha}$ ) fertilizers, herbicides, tractors and other farm equipment used in the agricultural subsystem. As a semi-perennial crop, energy cane is grown in a 6 year cycle with annual harvest. Cutting production, soil preparation and plantation are performed the first year (planted crop), and the remaining cultivation steps are repeated 6 times over the cycle (ratoon crop) (Fig. 2). The data and results used are therefore averages over a crop cycle and were collected from experimental trials $[12,47,48]$. The detail of agricultural operations and equipment for energy cane cultivation is given in Supplementary data (Table A.1). Harvested energy cane straw contains cane stalks, leaves, and cane trash (dry and partially detached leaves) with an average water content (w.c.) of $65 \%$. Cane tops are not exploited for energy purposes and are left on the field as crop residues. As climatic conditions are known to greatly influence sugarcane yields [49], we set different productivities for each island: 69.5 and 105.2 $\mathrm{t}$ fresh matter/ha of straw, respectively, for Grande-Terre and Basse-Terre Islands. However, fertilizer and pesticide application doses as well as other crop management parameters were assumed to be identical in both regional areas as actually advised by local extension services. Primary data inventory for the agricultural stage of energy cane can be found in Supplementary data (Table A.2).

\subsubsection{Pellet manufacturing}

Pellets are made from industrial residual yellow pine in Florida (United States). The LCI of manufacturing one ton of wood pellets was extracted from a generic process in the ecoinvent database and is representative of technologies used in a European context. As the pellet manufacturer and planning mill are considered to be on the same site, no transport of raw material was included. We adapted the electricity mix used for pelletization by using the US electricity mix. 


\subsubsection{Transport}

< Insert Figure 4 about here >

As shown in Fig. 4, energy cane and pellets follow different logistics paths. Wood pellets are transported by truck and rail from the manufacturer to the port. Then, import from Florida (UnitedStates) to Guadeloupe is assumed to be performed by transoceanic freight ship. From there, biomass is dispatched to the power plant using a 44t truck. The transportation of energy cane from the fields to the power plant is performed using a $14 \mathrm{t}$ agricultural trailer and then a $34 \mathrm{t}$ truck. The loading limits of trucks were adjusted to the transport densities of each biomass, as the assumed density is $200 \mathrm{~kg} / \mathrm{m}^{3}$ for energy cane and $700 \mathrm{~kg} / \mathrm{m}^{3}$ for pellets. The distances used are specified in Fig. 4 and correspond to the average distances between fields, freight stations and the expected location for the power plant in Guadeloupe. Fuel consumptions for biomass transport in Guadeloupe are also specified in Fig. 4. Generic fuel consumptions from ecoinvent database were used for others transports.

\subsubsection{Power plant}

Our case study involved a prospective $12 \mathrm{MW}_{\mathrm{e}}$ cogeneration plant producing electricity via a multifueled boiler accepting combustibles within a humidity range from 5 to $50 \%$ combined with a steam turbine system. The great degree of flexibility in fuel quality offers lower power efficiencies than regular monospecific boilers but it reduces economic risks for the industrial investors $[18,19,50]$. Energy cane straw underwent a pre-treatment (shredding, screening and drying process) producing $636 \mathrm{~kg}$ of dried chips with a final low heating value (LHV) of $2.28 \mathrm{MWh} / \mathrm{t} \mathrm{(45 \%} \mathrm{w.c.)} \mathrm{per}$ ton of fresh material. This LHV is lower than values found with a range of commonly used biomass materials (4.4 to 7.2 MWh/t) [51] and lower than the LHV of energy cane obtained in La Réunion (4.4 MWh/t) [31]. Wood pellets were burned without any supplementary pre-treatment and had a LHV of $4.40 \mathrm{MWh} / \mathrm{t}$ (5\% w.c.). The LHV of wood pellet is two times higher than LHV of dried 
energy cane, which induces the need for more biomass for generating the same thermic energy when the mix is based principally on energy cane. The boiler has a capacity of $40 \mathrm{MW}_{\text {th }}$ and functions $7800 \mathrm{~h} /$ year at full load with a yield of $89 \%$. Net energy conversion factor (26.42\%) for electricity production is within the range of 20-40\% usually obtained in biomass power plants [52], and the annual power production is $82.4 \mathrm{GWh}_{\mathrm{e}}$. Emissions data for $\mathrm{CO}_{2}, \mathrm{CO}, \mathrm{SO}_{2}$ and $\mathrm{NO}_{\mathrm{x}}$ resulting from boiler operating and biomass combustion can be found in the Supplementary data (Table A.3). Net $\mathrm{CO}_{2}$ emissions from biomass combustion was assumed nil because it was originally in the air before being absorbed by the plant during the growth of biomass, as it is generally assumed in many bioenergy LCAs $[17,53]$.

\subsubsection{Guadeloupean electricity mix}

In 2013 , the electricity production delivered to the grid was $1729 \mathrm{GWh}$ including $17.5 \%$ from renewable sources [54]. Shares of sources for the electricity production in Guadeloupe are described in Table 1. LCI values of electricity from fossil fuels were taken from the ecoinvent database v2.2 and are representative of average technologies in France with adaptations for the air emissions and fuels' origins. Gas emissions were adjusted from the annual declaration of pollutant emissions [55]. Fossil fuels are imported with oceanic ships from Venezuela (20\%) and Europe (80\%) and Venezuela (30\%) and Colombia (70\%) respectively for oil and hard coal. Bagasse is produced locally but the LCI was extracted from a process representative of bagasse as a co-product of sugar production in a Brazilian refinery. LCI of electricity from renewable sources (photovoltaic, hydropower, wind power, geothermal) were taken from Ecoinvent database and are representative of average technologies used in Europe.

$<$ Insert Table 1 about here > 


\subsection{Biomass provision scenarios}

\subsubsection{Modeling agricultural supply with a bio-economic model}

We modeled the production of energy cane in Guadeloupe with the MOSAICA model that simulates land use change scenario [56]. MOSAICA is a bio-economic model that simulates the mosaics of cropping systems at the landscape scale under different agricultural and policy contexts. It accounts for the constraints and opportunities at the field level (e.g., soil types and climate), the farm level (e.g., the availability of production factors), and the regional level (e.g., the market size). These constraints are traduced into mathematical equations that are then used in the optimization process to allocate cropping systems to fields. Potential fields eligible for energy cane farming are depicted on Fig. 3. Eligibility depends on fields' size, slope and soil type, and is aimed at providing consistent scenarios where energy cane cultivation is feasible from a biophysical point of view. The inputs of MOSAICA are i) a geographic database of fields, ii) the database of agricultural activities describing the cropping systems that can be allocated to fields and entailing the new energy cane activity, and iii) a farm typology that models farmers' risk aversion. To model the choice of cropping systems by farmers the model optimizes the overall utility of farmers, which includes the revenue and the risk aversion coefficient, which is the calibrating parameter, given the constraints defined above. The model was used in this study to simulate the adoption of energy cane cultivation by farmers. This new activity was defined with technical coefficients parameterized for each island, Basse-Terre and Grande-Terre, according to the results of the experimental trials conducted to assess the agronomic and economic performance of energy cane under real conditions.

\subsubsection{Scenario definition}

< Insert Table 2 about here >

Table 2 presents five scenarios established according to two factors: 1) the proportion of energy cane and pellets used in the biomass mix of the power plant and 2) the geographical areas targeted for the 
cultivation of energy cane in Guadeloupe. In the reference scenario (S1), boiler energy requirements were filled at $100 \%$ with energy cane. According to MOSAICA simulations, this biomass is grown on 2150 ha located at $85 \%$ in Basse-Terre Island and 15\% in Grande-Terre Island (Fig. 5). From this baseline, we designed scenarios S2 and S3 with a constraint on the geographical area of production: Basse-Terre Island only (S2) or Grande-Terre Island only (S3). The comparison of these two scenarios, S2 and S3, makes it possible to assess how spatial heterogeneity in the biomass production area influences LCA of the produced bioenergy. Energy cane is more profitable in Basse-Terre than in Grande Terre because the productivity is higher due to the better environmental conditions and the transport costs are lower due to the proximity to the power plant. Furthermore, as productivity on this island is higher, less area is needed when only this island is concerned. As a consequence, S2 requires 110 hectares less than S1, whereas S3 requires 938 hectares more (Fig. 5). Scenarios S1, S2 and S3 were designed to supply $215 \mathrm{kt}$ of harvested energy cane $\left(\mathrm{FU}_{2}\right)$ in order to fulfill boiler energy requirements. Scenario S4 was based on a multibiomass supply chain, as a way to secure provision of the power plant by diversifying the feedstock sources. Scenario S4 incorporates $30 \%$ of primary energy from imported wood pellets and 70\% from energy cane, which represent $150 \mathrm{kt}$ of harvested biomass, that is, 1539 ha cultivated in Basse-Terre and Grande-Terre and islands. According to the model's results, in this scenario S4, the energy cane grown comes mainly from grasslands and set-aside areas on Basse-Terre (respectively, $52 \%$ and $22 \%$ of the biomass supply), and $21 \%$ comes from set-aside areas located in Grande-Terre. In the last scenario (S5), the biomass provision is based only on imported wood pellets from Florida. The biomass feedstock requirement was calculated from the LHV of cane chips and pellets. Energy shares in the electricity mix were modified to generate six scenarios with the current Guadeloupean electricity mix (Table 1) as a base scenario (Mix GP). Oil and hard coal contributions were reduced by $2.5 \%$ each and were substituted for $5 \%$ of biomass electricity corresponding to the integration of the $12 \mathrm{MWe}$ power plant to the grid. Scenarios Mix S1 to Mix S5 were established from biomass provision scenarios S1 to S5. 
< Insert Figure 5 about here >

\subsection{Life Cycle Inventory Assessment}

\subsubsection{Field emissions}

To calculate the diffuse emissions of $\mathrm{N}$ and $\mathrm{P}$ from fertilizer application during crop cultivation, we used several models according to IPCC methodology [57] and experimental studies [58-61]. Field emissions were estimated distinctly in Basse-Terre and Grande-Terre for the major soil types occurring, i.e., respectively, ferralsols and vertisols:

- Ammonia volatilization $\left(\mathrm{NH}_{3}\right)$ to air was estimated using an emission factor set at $0.5 \%$ and $10 \%$ of $\mathrm{N}$ input from fertilizer, respectively, for Basse-Terre and Grande-Terre islands, as reported by previous studies in Guadeloupe. [58-60]. Differences between both islands about ammonium volatilization are linked to differences in soil $\mathrm{pH}$ (i.e. acid in Basse-Terre and basic in GrandeTerre). Nitrate $\left(\mathrm{NO}_{3}\right)$ leaching was estimated with a factor of $30 \%$ of $\mathrm{N}$ input from fertilizer as observed for the pedoclimatic conditions of Guadeloupe [61].

- Direct emissions of nitrous oxides $\left(\mathrm{N}_{2} \mathrm{O}\right)$ are due to soil nitrification and denitrification activities. We set a factor of $1 \%$ of $\mathrm{N}$ released as $\mathrm{N}_{2} \mathrm{O}$ from nitrogen fertilizer, as well as crop residue [57]. In addition, induced $\mathrm{N}_{2} \mathrm{O}$ emissions from nitrate leaching were calculated using a factor of $0.05 \%$ for $\mathrm{NO}_{3}$ which was found in a previous study in Guadeloupe [61]. Indirect $\mathrm{N}_{2} \mathrm{O}$ emissions from nitrate losses were considered with a factor of $1 \%$ for $\mathrm{NH}_{3}$ and $\mathrm{NO}_{\mathrm{x}}$ [57].

- P emissions to water via run-off, leaching and erosion were included [62]. Parameters considered were land use category, type of fertilizer, quantity of P spread and soil erosion. 


\subsubsection{Carbon stock changes from land conversion}

Each of the scenarios modeled with MOSAICA yields a land use change (LUC) in agricultural landscapes in Guadeloupe [63]. Land conversion generates the release or storage of carbon due to changes in soil organic content and in vegetation biomass. Emissions from different carbon stocks were calculated using the FAO Ex-Act tool [64] for a 25 year period, corresponding to the power plant lifetime. Initial and final land use was given by the MOSAICA model. Emissions from the conversion of temporary cropland set-asides to energy-cane was considered nil because those area actually account for set-aside perennial cropping systems (i.e. between successive sugarcane or banana crop cycle). Similarly, no emissions were considered for the conversion of sugarcane to energy cane. Land use change for wood provision in pellet manufacturing was already considered in the ecoinvent database process.

\subsubsection{Sensitivity analysis}

A sensitivity analysis was performed using a one-at-a-time approach in order to find the variability of LCIA results to two key input parameters: the energy cane LHV and the power plant net energy conversion factor. Variation in crop yields were not tested to avoid redundancy as it amounts to change the energy cane LHV. Impacts values were calculated per $\mathrm{kWh}$ produced with a $10 \%$ increase and decrease in each parameters, representing maximum uncertainty range. Feedstock from scenario S1 was used as baseline and changes in agricultural supply led to a linear increase or decrease from initial geographical repartition of energy cane fields between Basse-Terre and GrandeTerre. 


\section{Results and discussion}

\subsection{Spatial variability of the impacts of energy cane cultivation}

\subsubsection{Basse-Terre vs. Grande-Terre}

$<$ Insert Figure 6 about here >

To account for variability in the impacts of energy cane cultivation stage due to spatial heterogeneity, we compared the relative impacts of geographical cultivation areas in Guadeloupe (S1), Basse-Terre Island (S2) and Grande-Terre Island (S3) to their capacity to supply $215 \mathrm{kt}$ of biomass $\left(\mathrm{FU}_{2}\right)($ Fig. 6). This comparison shows that for all impact categories, S2 had the lowest impacts, while S3 had by far the highest, with a factor of 1.5 to 3.7 between impacts values. As suggested in Fig. 6, the impact values of the ABIOTIC DEPLETION and PHOTOCHEMICAL OXIDATION categories are strongly influenced by the geographical area of cultivation. For a decrease in productivity from 105 t/ha to 70 t/ha between S2 and S3, the cultivation area increased by $34 \%$ in S3 and as a consequence ABIOTIC DEPLETION and PHOTOCHEMICAL OXIDATION similarly increased. The variability was greater for other categories and was the highest for GLOBAL WARMING, with a factor of 3.7 between the S2 and S3 impact values.

\subsubsection{Contribution to GLOBAL WARMING at a regional scale}

< Insert Figure 7 about here >

The results presented in Fig. 6 are aggregated for the whole cultivation stage. In Fig. 7, we present a deeper focus, analyzing main agricultural process that contribute to GLOBAL WARMING to clearly identify emission sources. Soil emissions (land-use change and fertilizer emissions) dominated in S1 and S3 and represented $44 \%$ of the impact in S2. The results presented in Fig. 7 show that the differences in GLOBAL WARMING observed in Fig. 6 came principally from nitrogen fertilization, as associated emissions were eleven-fold higher in S3 than in S2. Lower agronomic productivity, mainly due to climatic conditions, with the same $\mathrm{N}$-fertilizer application dose led to an unfavorable 
$\mathrm{N}$ efficiency in the Grande-Terre area. In addition, low $\mathrm{pH}$ in ferralsols induced an inhibition of ammonia volatilization [58,59], and therefore indirect $\mathrm{N}_{2} \mathrm{O}$ emissions from fertilizer application were lower in S1 and S2 than in S3. Analogously, land-use change had a contrasted effect on GLOBAL WARMING depending on land conversion for energy crop cultivation. In S3, the emissions from land-use change were almost fivefold higher, as $90 \%$ of the feedstock supply area was originally former grasslands, while in S1 and S2, mostly set-aside or sugarcane areas were replaced by the energy crop. Spatial heterogeneity in fields at the landscape scale as well as land availability for energy crop cultivation are thus important factors in the variability of LCA results. Better understanding and accounting of theses parameters in ex-ante LCA might help to define pathways to reduce the contribution of agricultural processes to GLOBAL WARMING.

\subsection{Electricity from energy cane vs. wood pellets}

\subsubsection{Biomass production}

< Insert Table 3 about here >

< Insert Figure 8 about here >

In reference to the overall environmental performance of the bioenergy system, biomass production was the major contributor to the GLOBAL WARMING and ABIOTIC DEPLETION categories for both biomass resources, but energy cane cultivation had less impact than pellet manufacturing (Fig.

8). GLOBAL WARMING was similar for $\mathrm{S} 1$ and $\mathrm{S} 5$, with values of 0.234 and $0.237 \mathrm{~kg} \mathrm{CO}_{2}$ eq./kWh, respectively, even though biomass production had 30\% higher impacts in S5. Analysis of electricity from energy cane in La Reunion gave similar results $\left(0.199-0.298 \mathrm{~kg} \mathrm{CO}_{2}\right.$ eq./kWh $)$ with harvesting yields ranging from 80 to $160 \mathrm{t}$ fresh matter/ha. In comparison, impact values from bagasse derived electricity with cogeneration process varied much between studies with $0.260 \mathrm{~kg}$ $\mathrm{CO}_{2}$ eq./kWh found in Australia [33] and $0.882-1.17 \mathrm{~kg} \mathrm{CO}_{2}$ eq./kWh in Brazil [30]. Anyway, 
these LCIA results are superior to the median of $0.115 \mathrm{~kg} \mathrm{CO}_{2}$ eq. $/ \mathrm{kWh}$ obtained in the comparison of eighty-eight bioenergy systems scenarios for the production of electricity [17].

The inventory of emissions in Table 3 specifies that impact originates more from biogenic sources in $\mathrm{S} 1$ and $\mathrm{S} 4$, as we observe higher emissions of $\mathrm{CO}_{2}$ from land conversion and, conversely, a greater amount of $\mathrm{CO}_{2}$ fossil emissions coming from the technosphere in S5. The results for the ABIOTIC DEPLETION category confirm that S5 required 29\% more primary energy than S1, mainly because of the amount of electricity used for palletization (Fig. 8). Thus, energy cane provided better energy returns regarding fossil energy consumption in the input-output equation.

Biomass production also had a strong influence on the EUTROPHICATION impact for S1 and S4, as energy cane cultivation accounted for 70 and $61 \%$ of the impact, whereas in S5, pellet manufacturing had a low contribution to this category (25\%). This result is mostly due to diffuse emissions of $\mathrm{NO}_{3}$ and phosphate after fertilizer application, thus the values were lower in $\mathrm{S} 5$ where no energy cane is used (Table 3). As a result, EUTROPHICATION impact values were almost threefold higher for S1 than for S5 due to avoiding the emissions of energy cane fertilization.

\subsubsection{Transport}

The transport stage did not exhibit a large effect on the environmental performances of S1 and S4, as it represented only $1 \%-13 \%$ of the total system impacts for the GLOBAL WARMING, ABIOTIC DEPLETION, ACIDIFICATION, EUTROPHICATION and PHOTOCHEMICAL OXIDATION categories. However, in the S5 results, the transport contribution accounted for $13-19 \%$ of the total impacts for the same categories. The primary fossil energy consumed for transport was $50 \%$ higher in S5 compared to S1 indicating that oceanic freight transport led to a higher contribution to ABIOTIC DEPLETION. However, considering the long distance transport of wood pellets compared to local energy cane (2650 Vs $50 \mathrm{~km})$, we expected a higher difference in primary fossil energy use for transport phase. Comparable results were obtained by Favero et Pettenella [39] for the import of 
woody biomass in Italy, confirming that maritime transport shows good energy efficiency. However, the transport impact values of S5 were systematically higher, particularly in the PHOTOCHEMICAL OXIDATION and ACIDIFICATION categories, with emissions fourfold to sixfold higher, respectively, than for $\mathrm{S} 1$. As expected, the energy cane logistics was more environmentally friendly.

\subsubsection{Power plant}

The power plant stage made a high contribution to the ACIDIFICATION and PHOTOCHEMICAL OXIDATION categories, in particular for S4 (65\% for both categories) and S1 (77\% and 80\%), but S5 had more impact, with total impact values 29\% higher than in S1 (Figure 8). The impacts were principally related to $\mathrm{NO}_{\mathrm{x}}$ and $\mathrm{SO}_{2}$ emissions from biomass combustion. The conversion stage also had an important effect on other impact categories. For all categories, we observed a reduction of power plant emissions with the use of pellets, as no pre-treatment is performed for this combustible. However, the higher impact values of S5 compared to S1, except for EUTROPHICATION, indicate that the environmental benefits acquired in the power plant stage were balanced with higher emissions during transport and biomass production.

\subsubsection{Sensitivity analysis}

Logically, the sensitivity analysis with power plant energy conversion factor and energy cane LHV showed almost identical results, thus only results for the first parameter are given in Supplementary data (Table A.4). LCIA results varied from about 4 to $11 \%$ depending on impact categories. LAND OCCUPATION and GLOBAL WARMING were the most influenced impact categories with values ranging respectively from 4.29 to $5.24 \mathrm{~m}^{2}$.year $/ \mathrm{kWh}$ and from 0.217 to $0.256 \mathrm{~kg} \mathrm{CO}_{2}$ eq. $/ \mathrm{kWh}$. ABIOTIC DEPLETION ranged from 2.20 to $2.55 \mathrm{MJ} / \mathrm{kWh}$. The energy returned on fossil energy invested remained less than 1 as less than $3.6 \mathrm{MJ}$ (equivalent to $1 \mathrm{kWh}$ ) of fossil energy was used to produce $1 \mathrm{kWh}$ of bioeletricity. 


\subsection{Impacts of introducing a $5 \%$ fraction of biomass into the electricity mix}

< Insert Figure 9 about here >

The impacts due to the substitution of $5 \%$ of fossil for biomass energy in the Guadeloupe electricity mix were examined and compared for all biomass provisions scenarios (Figure 9). LCIA results for $1 \mathrm{kWh}$ of energy produced from each biomass provision scenarios can be found in supplementary data (Table A.5). LCI values for fossil and other renewable sources than energy cane were taken from generic process in the ecoinvent database. Although differences in system boundaries and time periods among the three systems may limit the comparison, and environmental impacts may differ slightly between small-scale power plants located in Guadeloupe and larger plants in Europe, our results permit the examination of the main environmental advantages and drawbacks of incorporating biomass-derived electricity into the mix of Guadeloupe that rely heavily on fossil fuels. The results presented in Fig. 9 indicate that grid integration of a $12 \mathrm{MW}_{\mathrm{e}}$ biomass power plant led to better environmental performances in four of the six selected impact categories and that overall differences in impacts were moderate except for LAND OCCUPATION category. Bioenergy reduced GLOBAL WARMING by $4.5 \%$ (36 $\mathrm{CO}_{2}$ eq./kWh) in all scenarios except $\mathrm{S} 4$, which presented a $2.9 \%$ reduction $\left(23 \mathrm{~g} \mathrm{CO}_{2}\right.$ eq. $\left./ \mathrm{kWh}\right)$ compared to the baseline electricity mix. Similarly, ABIOTIC DEPLETION decreased by $4.2 \%$ with $5 \%$ biomass substituting hard coal and oil. Thus, based on the assumptions we made, biomass electricity can support the net reduction of fossil fuel use for power generation in Guadeloupe. In contrast, the scenarios including biomass energy performed poorly in EUTROPHICATION and LAND OCCUPATION. For EUTROPHICATION, scenarios using exclusively energy cane as biomass energy carrier in power plant had EUTROPHICATION impacts increased by 0.1 to $3.1 \%$ for S3. However, EUTROPHICATION was reduced by $0.7 \%$ and $3.6 \%$ respectively with incorporation of $30 \%$ and $100 \%$ of wood pellets in the biomass power plant. Depending on the scenario, electricity production 
required 3.5 to 5.2 times more land than without biomass penetration in the electricity mix. The electric demand for the 400000 inhabitants of the island is actually provided at a rate of $82.5 \%$ by

fossil sources. Based on our previous assumptions, in order to substitute a quarter of the electricity currently provided by fossil sources in Guadeloupe using only energy cane biomass (which represents an annual production of $347 \mathrm{GWh}$ ), the land needed for cultivating energy cane would be at least $33 \%$ of the total agricultural area of the island. Consequently, the replacement of conventional energy resources with biomass in small islands should be limited by land availability for energy purposes unless imported and local resources are combined to supply the power plant.

\section{Conclusion}

Our study aimed to perform an LCA analysis of electricity production from energy cane in Guadeloupe, a specifically selected sugarcane cultivar dedicated only to energy purposes. Our results show that substitution of fossil fuels for this biomass energy source can participate to produce cleaner electricity and support energy transition in small tropical islands. Locally grown energy cane exhibited better environmental performances than imported wood pellets, particularly in the ABIOTIC DEPLETION, ACIDIFICATION and PHOTOCHEMICAL OXIDATION categories. However, electricity from pellets decreased the EUTROPHICATION impact by threefold because it avoids the emissions of energy cane fertilization. The agricultural stage played a key role in the system's environmental behavior, and high impact variability was observed between geographical areas of production, with factors varying from 1.5 for the ABIOTIC DEPLETION and PHOTOCHEMICAL OXIDATION categories to 3.7 for GLOBAL WARMING. Better environmental profiles were obtained in Basse-Terre Island, as lower productivities in Grande-Terre combined with higher soil emissions after fertilizer application and important grassland conversion make this area less suitable for energy crop deployment. These findings encourage accounting more systematically for spatial heterogeneity in agricultural fields in the LCA of bioenergy. The 
substitution of $5 \%$ of fossil energy for biomass in the island electricity mix can support climate change mitigation and fossil energy autonomy, as it provides electricity that can reduce GLOBAL WARMING and ABIOTIC DEPLETION impact by $4.5 \%$. However, those environmental benefits must be balanced with LAND OCCUPATION, which was 3.5 to 5.2 higher per unit of energy produced. Land competition with other land uses such as food production should be further studied but might be limited, as only grasslands or under-utilized lands, set-asides and sugarcane croplands were converted for energy cane farming in compared scenarios. The diversification of feedstock, particularly with imported biomass, can limit LAND OCCUPATION but will reduce environmental benefits.

Before policy decisions are made, social acceptability and economic viability must also be verified to balance the pros and cons of biomass-based energy. Our conclusions regarding the environmental sustainability of the bioenergy system should be completed with a wider range of indicators, for example, to measure the impact on biodiversity or soil organic matter evolution, which are issues of primary importance under tropical conditions. Furthermore, a consequential LCA approach would be the next step to obtain a broader view of environmental benefits and the trade-offs of converting various lands to grow energy crops.

\section{Acknowledgments}

This work was financially supported by Region Guadeloupe via the European Regional Development Fund (FEDER) Guadeloupe in the framework of the REBECCA project, Phase 2 (FEDER 2007-2013 $\left.n^{\circ} 1 / 1.4 /-33634\right)$. The authors gratefully acknowledge the members of UMR Sol Agro et hydrosystème Spatialisation for assisting in the realization of this work.

\section{Appendix A. Supplementary data.}

Supplementary data associated with this article can be found in the online version of the article. 


\section{References}

[1] G. Notton, Importance of islands in renewable energy production and storage: The situation of the French islands, Renew. Sustain. Energy Rev. 47 (2015) 260-269. doi:10.1016/j.rser.2015.03.053.

[2] M. Drouineau, E. Assoumou, V. Mazauric, N. Maïzi, Increasing shares of intermittent sources in Reunion Island: Impacts on the future reliability of power supply, Renew. Sustain. Energy Rev. 46 (2015) 120-128. doi:10.1016/j.rser.2015.02.024.

[3] E.K. Stuart, Energizing the island community: A review of policy standpoints for energy in small island states and territories, Sustain. Dev. 14 (2006) 139-147.

[4] D. Weisser, On the economics of electricity consumption in small island developing states: A role for renewable energy technologies?, Energy Policy. 32 (2004) 127-140.

[5] S. Gold, S. Seuring, Supply chain and logistics issues of bio-energy production, J. Clean. Prod. 19 (2011) 32-42. doi:10.1016/j.jclepro.2010.08.009.

[6] Guadeloupe Énergie, Plan énergétique Régional pluriannuel de prospection et d'exploitation des Énergies Renouvelables et d'Utilisation Rationnelle de l'Énergie de la Guadeloupe (PRERURE), 2012. http://www.guadeloupe-energie.gp/wpcontent/uploads/PRERURE_Guadeloupe_sept2012-1.pdf.

[7] M.R.L.V. Leal, M. V. Galdos, F. V. Scarpare, J.E.A. Seabra, A. Walter, C.O.F. Oliveira, Sugarcane straw availability, quality, recovery and energy use: A literature review, Biomass and Bioenergy. 53 (2013) 11-19. doi:10.1016/j.biombioe.2013.03.007.

[8] D. Sabatier, J.F. Martiné, F. Chiroleu, C. Roussel, P. Letourmy, R. van Antwerpen, B. Gabrielle, B. Ney, Optimization of sugarcane farming as a multipurpose crop for energy and food production, GCB Bioenergy. 579 (2014) 40-56. doi:10.1111/gcbb.12133.

[9] M.R.L. V. Leal, A.S. Walter, J.E.A. Seabra, Sugarcane as an energy source, Biomass Convers. Biorefinery. 3 (2012) 17-26. doi:10.1007/s13399-012-0055-1.

[10] S. Matsuoka, A.J. Kennedy, E.G.D. Dos Santos, A.L. Tomazela, L.C.S. Rubio, Energy Cane: Its Concept, Development, Characteristics, and Prospects, Adv. Bot. 2014 (2014) 1-13. doi:10.1155/2014/597275.

[11] O. V Carvalho-Netto, J.A. Bressiani, H.L. Soriano, C.S. Fiori, J.M. Santos, G.V. Barbosa, M.A. Xavier, M.G. Landell, G.A. Pereira, The potential of the energy cane as the main biomass crop for the cellulosic industry, Chem. Biol. Technol. Agric. 1 (2014) 20. doi:10.1186/s40538-014-0020-2.

[12] J. Sierra, J.L. Chopart, L. Guindé, J.M. Blazy, Optimization of Biomass and Compost Management to Sustain Soil Organic Matter in Energy Cane Cropping Systems in a Tropical Polluted Soil: a Modelling Study, BioEnergy Res. 9 (2016) 798-808. doi:10.1007/s12155016-9729-z.

[13] A.G. Alexander, The energy cane alternative, Sugar seri, Elsevier Science Publishers, New York, 1985.

[14] J.-L. Chopart, B. Bachelier, Propriétés et performances comparées de 16 cultivars de Poacées (Saccharum sp. et Erianthus) en vue d'un usage énergétique, in: Proc. Congrès AFCAS ARTAS, s.n., La Réunion, France, 2012. https://agritop.cirad.fr/566633 (accessed September 30, 2015).

[15] C. Godard, J. Boissy, B. Gabrielle, Life-cycle assessment of local feedstock supply scenarios to compare candidate biomass sources, GCB Bioenergy. 5 (2013) 16-29. doi:10.1111/j.1757- 
1707.2012.01187.x.

[16] F. Cherubini, A.H. Strømman, Life cycle assessment of bioenergy systems: state of the art and future challenges., Bioresour. Technol. 102 (2011) 437-51.

doi:10.1016/j.biortech.2010.08.010.

[17] S. Muench, E. Guenther, A systematic review of bioenergy life cycle assessments, Appl. Energy. 112 (2013) 257-273. doi:10.1016/j.apenergy.2013.06.001.

[18] A.A. Rentizelas, A.J. Tolis, I.P. Tatsiopoulos, Logistics issues of biomass: The storage problem and the multi-biomass supply chain, Renew. Sustain. Energy Rev. 13 (2009) 887894. doi:10.1016/j.rser.2008.01.003.

[19] A.A. Rentizelas, I.P. Tatsiopoulos, A. Tolis, An optimization model for multi-biomass trigeneration energy supply, Biomass and Bioenergy. 33 (2009) 223-233. doi:10.1016/j.biombioe.2008.05.008.

[20] T. Tahvanainen, P. Anttila, Supply chain cost analysis of long-distance transportation of energy wood in Finland, Biomass and Bioenergy. 35 (2011) 3360-3375. doi:10.1016/j.biombioe.2010.11.014.

[21] D. Reed, R. Bergman, J.W. Kim, a Taylor, D. Harper, D. Jones, C. Knowles, M.E. Puettmann, Cradle-to-gate life-cycle inventory and impact assessment of wood fuel pellet manufacturing from hardwood flooring residues in the southeastern United States, For. Prod. J. 62 (2012) 280-288. doi:10.13073/FPJ-D-12-00015.1.

[22] P.A. Fokaides, L. Tofas, P. Polycarpou, A. Kylili, Sustainability aspects of energy crops in arid isolated island states: the case of Cyprus, Land Use Policy. 49 (2015) 264-272. doi:10.1016/j.landusepol.2015.08.010.

[23] J.E.A. Seabra, I.C. Macedo, H.L. Chum, C.E. Faroni, C.A. Sarto, Life cycle assessment of Brazilian sugarcane products: GHG emissions and energy use, Biofuels, Bioprod. Biorefining. 5 (2011) 519-532. doi:10.1002/bbb.289.

[24] T. Ramjeawon, Life cycle assessment of electricity generation from bagasse in Mauritius, J. Clean. Prod. 16 (2008) 1727-1734. doi:10.1016/j.jclepro.2007.11.001.

[25] L. Mashoko, C. Mbohwa, V.M. Thomas, Life cycle inventory of electricity cogeneration from bagasse in the South African sugar industry, J. Clean. Prod. 39 (2013) 42-49. doi:10.1016/j.jclepro.2012.08.034.

[26] M. Pérez Gil, A.M. Contreras Moya, E. Rosa Domínguez, Life cycle assessment of the cogeneration processes in the Cuban sugar industry, J. Clean. Prod. 41 (2013) 222-231. doi:10.1016/j.jclepro.2012.08.006.

[27] M.A. Renouf, R.J. Pagan, M.K. Wegener, Bio-production from Australian sugarcane: An environmental investigation of product diversification in an agro-industry, J. Clean. Prod. 39 (2013) 87-96. doi:10.1016/j.jclepro.2012.08.036.

[28] O. Cavalett, T.L. Junqueira, M.O.S. Dias, C.D.F. Jesus, P.E. Mantelatto, M.P. Cunha, H.C.J. Franco, T.F. Cardoso, R. Maciel Filho, C.E. V. Rossell, A. Bonomi, Environmental and economic assessment of sugarcane first generation biorefineries in Brazil, Clean Technol. Environ. Policy. 14 (2011) 399-410. doi:10.1007/s10098-011-0424-7.

[29] M.J. Amores, F.D. Mele, L. Jiménez, F. Castells, Life cycle assessment of fuel ethanol from sugarcane in Argentina, Int. J. Life Cycle Assess. 18 (2013) 1344-1357. doi:10.1007/s11367013-0584-2.

[30] J.P.M. Guerra, J.R. Coleta, L.C.M. Arruda, G.A. Silva, L. Kulay, Comparative analysis of electricity cogeneration scenarios in sugarcane production by LCA, Int. J. Life Cycle Assess. 
(2014) 1-12. doi:10.1007/s11367-014-0702-9.

[31] J. Masson, C. Lejars, J.L. Fusillier, S. Auzoux, C. Poser, Assessing economic and environmental benefits of dedicated energy cane using a simulation tool : ReefCane ${ }^{\circledR}$, Sugar Ind. 142 (5) (2017) 270-276.

[32] M.A. Renouf, M.K. Wegener, R.J. Pagan, Life cycle assessment of Australian sugarcane production with a focus on sugarcane growing, Int. J. Life Cycle Assess. 15 (2010) 927-937. doi:10.1007/s11367-010-0226-X.

[33] A.M. Renouf, R.J. Pagan, M.K. Wegener, Life cycle assessment of Australian sugarcane products with a focus on cane processing, Int. J. Life Cycle Assess. 16 (2011) 125-137. doi:10.1007/s11367-010-0233-y.

[34] M. Röder, C. Whittaker, P. Thornley, How certain are greenhouse gas reductions from bioenergy? Life cycle assessment and uncertainty analysis of wood pellet-to-electricity supply chains from forest residues, Biomass and Bioenergy. 79 (2015) 50-63. doi:10.1016/j.biombioe.2015.03.030.

[35] J. Hansson, F. Martinsson, M. Gustavsson, Greenhouse gas performance of heat and electricity from wood pellet value chains - based on pellets for the Swedish market, Biofuels, Bioprod. Biorefining. 9 (2015) 378-396. doi:10.1002/bbb.1538.

[36] G. Forsberg, Biomass energy transport, Biomass and Bioenergy. 19 (2000) 17-30. doi:10.1016/S0961-9534(00)00020-9.

[37] C.N. Hamelinck, R.A.A. Suurs, A.P.C. Faaij, International bioenergy transport costs and energy balance, Biomass and Bioenergy. 29 (2005) 114-134. doi:10.1016/j.biombioe.2005.04.002.

[38] K. Damen, A. Faaij, A Greenhouse Gas Balance of two Existing International Biomass Import Chains, Mitig. Adapt. Strateg. Glob. Chang. 11 (2006) 1023-1050. doi:10.1007/s11027-0069032-y.

[39] M. Favero, D. Pettenella, Italian import flows of woody biomasses for energy use: a sustainable supply?, New Medit. 13 (2014) 56-64.

[40] H. Eswaran, F.H. Beinroth, J. Kimble, T. Cook, Soil diversity in the tropics: Implications for agricultural development, SSSA Spec. Publ. 29 (1992) 1-16.

[41] P. Maurizot, H. Théveniaut, P. Lecomte, Y.-M. Cabidoche, Enjeux géologiques propres aux territoires tropicaux, Geosciences. 14 (2011) 22-31. https://hal-brgm.archives-ouvertes.fr/hal00662090/document (accessed July 27, 2015).

[42] J.B. Guinée, R. Heijungs, G. Huppes, R. Kleijn, A. de Koning, L. van Oers, A. Wegener Sleeswijk, S. Suh, H.A. Udo de Haes, H. de Bruijn, R. van Duin, M.A.J. Huijbregts, M. Gorrée, Handbook on Life Cycle Assessment. An Operational Guide to the ISO Standards, Kluwer Academic Publishers, Dordrecht, The Netherland, 2002.

http://scholar.google.com/scholar?hl=en\&btnG=Search\&q=intitle:\%22Life+Cycle+Assessme nt:+An+Operational+Guide+to+the+ISO+Standards\%22+Part+2A,+'Guide'\#0.

[43] M. Goedkoop, R. Heijungs, M. Huijbregts, A. De Schryver, J. Struijs, R. Van Zelm, ReCiPe 2008, A life cycle impact assessment method which comprises harmonised category indicators at the midpoint and the endpoint level; First edition Report I: Characterisation, 2009. http://www.lcia-recipe.net.

[44] R. Frischknecht, N. Jungbluth, H.-J. Althaus, G. Doka, R. Dones, T. Heck, S. Hellweg, R. Hischier, T. Nemecek, G. Rebitzer, M. Spielmann, The ecoinvent Database: Overview and Methodological Framework, Int. J. Life Cycle Assess. 10 (2005) 3-9. 
doi:10.1065/lca2004.10.181.1.

[45] V. Colomb, S.A. Amar, C.B. Mens, A. Gac, G. Gaillard, P. Koch, J. Mousset, T. Salou, A. Tailleur, H.M.G. van der Werf, AGRIBALYSE, the French LCI database for agricultural products: high quality data for producers and environmental labelling., OCL - Oilseeds Fats, Crop. Lipids. 22 (2015) D104. doi:10.1051/ocl/20140047.

[46] CLIMAT ANTILLES GUYANE - Informations, normales et statistiques sur le climat en Antilles (Guadeloupe, Martinique) et Guyane, (n.d.). http://www.meteofrance.gp (accessed July 8, 2015).

[47] J.-F. Martiné, C. Poser, C. Roussel, G. Edward, J.-L. Chopart, Modelling energy cane growth in contrasting environments: calibration and validation, in: 2016 Chiang Mai : Thailand Society of Sugar Cane Technologists (Ed.), 29th Congr. Int. Soc. Sugar Cane Technol. Abstr. Book., Allsop Pet, TSSCT, ISSCT, Chiang Mai, Thailand, 2016: pp. 68-69.

[48] J.-L. Chopart, Two high-fibre sugarcane varieties adapted for energy use in Guadeloupe, in: Chiang Mai : Thailand Society of Sugar Cane Technologist (Ed.), 29th Congr. Int. Soc. Sugar Cane Technol. Abstr. B., Allsop Pet, TSSCT, ISSCT, Chiang Mai, Thailand, 2016: p. 79.

[49] S. Pellerin, Etude d'une série chronologique de rendements en canne à sucre obtenus en Guadeloupe à partir d'un modèle de simulation du bilan hydrique, Agronomie. 6 (1986) 9198. doi:10.1051/agro:19860108.

[50] N. Magasiner, The effect of fuel moisture content on the performance of typical bagasse fired watertube boiler, in: John Thompson Africa (Pty) (Ed.), South African Sugar Technol. Assoc., Belleville, Cape, 1987: pp. 86-89.

[51] P. McKendry, Energy production from biomass (part 1): overview of biomass, Bioresour. Technol. 83 (2002) 37-46. doi:10.1016/S0960-8524(01)00118-3.

[52] P. McKendry, Energy production from biomass (part 2): Conversion technologies, Bioresour. Technol. 83 (2002) 47-54. doi:10.1016/S0960-8524(01)00119-5.

[53] A. Rabl, A. Benoist, D. Dron, B. Peuportier, J. V. Spadaro, A. Zoughaib, How to account for CO2 emissions from biomass in an LCA, Int. J. Life Cycle Assess. 12 (2007) 281-281. doi:10.1065/lca2007.06.347.

[54] OREC, Les chiffres clés de l'énergie en Guadeloupe Bilan 2013, (2014).

[55] iREP, Répertoire du Registre français des émissions polluantes sur Internet, (n.d.). http://www.irep.ecologie.gouv.fr/IREP/index.php (accessed May 13, 2015).

[56] P. Chopin, T. Doré, L. Guindé, J.-M. Blazy, MOSAICA: A multi-scale bioeconomic model for the design and ex ante assessment of cropping system mosaics, Agric. Syst. 140 (2015) 26-39. doi:10.1016/j.agsy.2015.08.006.

[57] IPCC 2006, 2006 IPCC Guidelines for National Greenhouse Gas Inventories, Prepared by the National Greenhouse Gas Inventories Programme, Eggleston H.S., Buendia L., Miwa K., Ngara T. and Tanabe K. (eds), in: IGES, Japan, 2006.

[58] J. Sierra, S. Fontaine, L. Desfontaines, Factors controlling N mineralization, nitrification, and nitrogen losses in an Oxisol amended with sewage sludge, Aust. J. Soil Res. 39 (2001) 519534. doi:10.1071/SR00026.

[59] J. Sierra, A hot-spot approach applied to nitrification in tropical acid soils, Soil Biol. Biochem. 38 (2006) 644-652. doi:10.1016/j.soilbio.2005.06.016.

[60] N. Courtaillac, Maîtrise du cycle de l'azote dans le système vertisol - canne à sucre Conséquences sur la gestion des parcelles, Ecole Nationale Supérieure d'Agronomie et des 
Industries Alimentaires, 1998.

[61] J. Sierra, N. Brisson, D. Ripoche, C. Noël, Application of the STICS crop model to predict nitrogen availability and nitrate transport in a tropical acid soil cropped with maize, Plant Soil. 256 (2003) 333-345. doi:10.1023/A:1026106208320.

[62] T. Nemecek, T. Kägi, Life Cycle Inventories of Swiss and European Agricultural Production Systems. Final Report Ecoinvent V.2.0 No. 15a., Zurich and Dübendorf, CH, 2007. http://db.ecoinvent.org/reports/15_Agriculture.pdf (accessed May 11, 2015).

[63] P. Forster, V. Ramaswamy, P. Artaxo, T. Berntsen, R. Betts, D.W. Fahey, J. Haywood, J. Lean, D.C. Lowe, G. Myhre, J. Nganga, R. Prinn, G. Raga, M. Schulz, R. Van Dorland, Changes in Atmospheric Constituents and in Radiative Forcing, in: Clim. Chang. 2007 Phys. Sci. Basis. Contrib. Work. Gr. I to Fourth Assess. Rep. Intergov. Panel Clim. Chang., Cambridge University Press, 2007: pp. 129-234.

[64] FAO, EX-ACT Tool, (n.d.). http://www.fao.org/tc/exact/carbon-balance-tool-ex-act/en/ (accessed May 11, 2015).

\begin{tabular}{ll}
\hline Energy sources & Shares (\%) \\
\hline Imported fossil fuels & \\
Hard Coal & 51.5 \\
Oil & 31.0 \\
Local and renewable source & \\
Photovoltaics & 5.7 \\
Geothermal & 4.7 \\
Wind energy & 3.3 \\
Bagasse & 2.7 \\
Hydroelectricity & 1.1 \\
\hline
\end{tabular}

Table 1 - Electricity mix in Guadeloupe in 2013. 


\begin{tabular}{lll}
\hline Scenarios & $\begin{array}{l}\text { Percentage of energy } \\
\text { cane VS wood pellets }\end{array}$ & $\begin{array}{l}\text { Biomass geographical origin } \\
\text { (\% of total energy cane mass harvested) }\end{array}$ \\
\hline S1 & $100 \% / 0 \%$ & Basse-Terre (90\%) and Grande-Terre (10\%) islands (Guadeloupe) \\
S2 & $100 \% / 0 \%$ & Basse-Terre Island (100\%) \\
S3 & $100 \% / 0 \%$ & Grande-Terre Island (100\%) \\
S4 & $70 \% / 30 \%$ & Basse-Terre (85\%) and Grande-Terre (15\%) islands (Guadeloupe) \\
S5 & $0 \% / 100 \%$ & Florida (United-States) \\
\hline
\end{tabular}

Table 2 - Feedstock supply scenarios for the production of electricity. 


\begin{tabular}{|c|c|c|c|c|c|c|}
\hline Substance emitted & Compartment & S1 & S2 & S3 & S4 & S5 \\
\hline $\begin{array}{l}\mathrm{CO}_{2} \text { from land } \\
\text { conversion }\end{array}$ & Air & $\begin{array}{l}\text { 3.51E-02 } \\
(21 \%)\end{array}$ & $\begin{array}{l}\text { 3.51E-02 } \\
(21 \%)\end{array}$ & $\begin{array}{l}1.64 \mathrm{E}-01 \\
(100 \%)\end{array}$ & $\begin{array}{l}3.51 \mathrm{E}-02 \\
(21 \%)\end{array}$ & $\begin{array}{l}1.21 \mathrm{E}-05 \\
(0 \%)\end{array}$ \\
\hline $\mathrm{CO}_{2}$ fossil & Air & $\begin{array}{l}1.64 \mathrm{E}-01 \\
(73 \%)\end{array}$ & $\begin{array}{l}\text { 1.61E-01 } \\
(71 \%)\end{array}$ & $\begin{array}{l}1.90 \mathrm{E}-01 \\
(84 \%)\end{array}$ & $\begin{array}{l}1.84 \mathrm{E}-01 \\
(81 \%)\end{array}$ & $\begin{array}{l}2.26 \mathrm{E}-01 \\
(100 \%)\end{array}$ \\
\hline $\mathrm{SO}_{2}$ & Air & $\begin{array}{l}1.01 \mathrm{E}-03 \\
(58 \%)\end{array}$ & $\begin{array}{l}1.01 \mathrm{E}-03 \\
(58 \%)\end{array}$ & $\begin{array}{l}1.08 \mathrm{E}-03 \\
(62 \%)\end{array}$ & $\begin{array}{l}1.23 \mathrm{E}-03 \\
(71 \%)\end{array}$ & $\begin{array}{l}1.73 \mathrm{E}-03 \\
(100 \%)\end{array}$ \\
\hline $\mathrm{N}_{2} \mathrm{O}$ & Air & $\begin{array}{l}\text { 1.04E-04 } \\
(20 \%)\end{array}$ & $\begin{array}{l}5.48 \mathrm{E}-05 \\
(10 \%)\end{array}$ & $\begin{array}{l}5.25 \mathrm{E}-04 \\
(100 \%)\end{array}$ & $\begin{array}{l}9.01 \mathrm{E}-05 \\
(17 \%)\end{array}$ & $\begin{array}{l}\text { 7.67E-06 } \\
(1 \%)\end{array}$ \\
\hline NOx & Air & $\begin{array}{l}2.04 \mathrm{E}-03 \\
(97 \%)\end{array}$ & $\begin{array}{l}\text { 2.02E-03 } \\
(96 \%)\end{array}$ & $\begin{array}{l}1.15 \mathrm{E}-03 \\
(55 \%)\end{array}$ & $\begin{array}{l}2.11 \mathrm{E}-03 \\
(100 \%)\end{array}$ & $\begin{array}{l}2.08 \mathrm{E}-03 \\
(99 \%)\end{array}$ \\
\hline $\mathrm{NH}_{3}$ & Air & $\begin{array}{l}6.27 \mathrm{E}-05 \\
(46 \%)\end{array}$ & $\begin{array}{l}5.42 \mathrm{E}-05 \\
(40 \%)\end{array}$ & $\begin{array}{l}1.35 \mathrm{E}-04 \\
(100 \%)\end{array}$ & $\begin{array}{l}4.95 \mathrm{E}-05 \\
(37 \%)\end{array}$ & $\begin{array}{l}1.02 \mathrm{E}-05 \\
(8 \%)\end{array}$ \\
\hline $\mathrm{NO}_{3}$ & Water & $\begin{array}{l}4.33 \mathrm{E}-03 \\
(70 \%)\end{array}$ & $\begin{array}{l}4.11 \mathrm{E}-03 \\
(66 \%)\end{array}$ & $\begin{array}{l}6.22 \mathrm{E}-03 \\
(100 \%)\end{array}$ & $\begin{array}{l}3.11 \mathrm{E}-03 \\
(50 \%)\end{array}$ & $\begin{array}{l}1.78 \mathrm{E}-05 \\
(0 \%)\end{array}$ \\
\hline Phosphate & Water & $\begin{array}{l}1.82 \mathrm{E}-04 \\
(74 \%)\end{array}$ & $\begin{array}{l}1.74 \mathrm{E}-04 \\
(71 \%)\end{array}$ & $\begin{array}{l}2.45 \mathrm{E}-04 \\
(100 \%)\end{array}$ & $\begin{array}{l}1.39 \mathrm{E}-04 \\
(57 \%)\end{array}$ & $\begin{array}{l}6.62 \mathrm{E}-07 \\
(0 \%)\end{array}$ \\
\hline
\end{tabular}

Table 3 - Inventory of emissions of the bioenergy system for the five scenarios, expressed in $\mathrm{kg}$ per functional unit ( $1 \mathrm{kWh}$ electricity) and as a percentage of the largest impact in each category. 


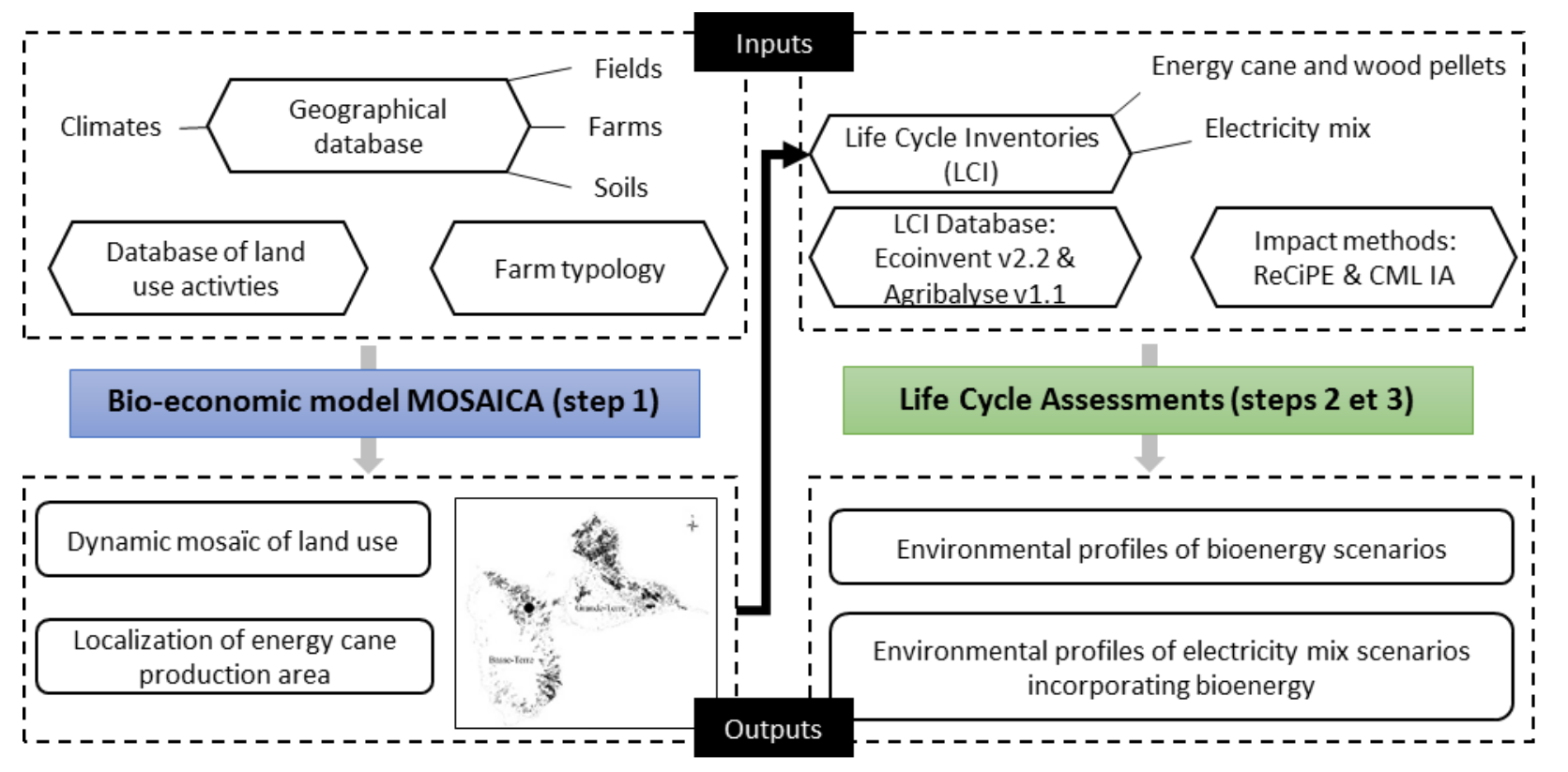

Fig. 1 - Overview of the approach for ex ante assessment of biomass provision scenarios at the territory scale. 


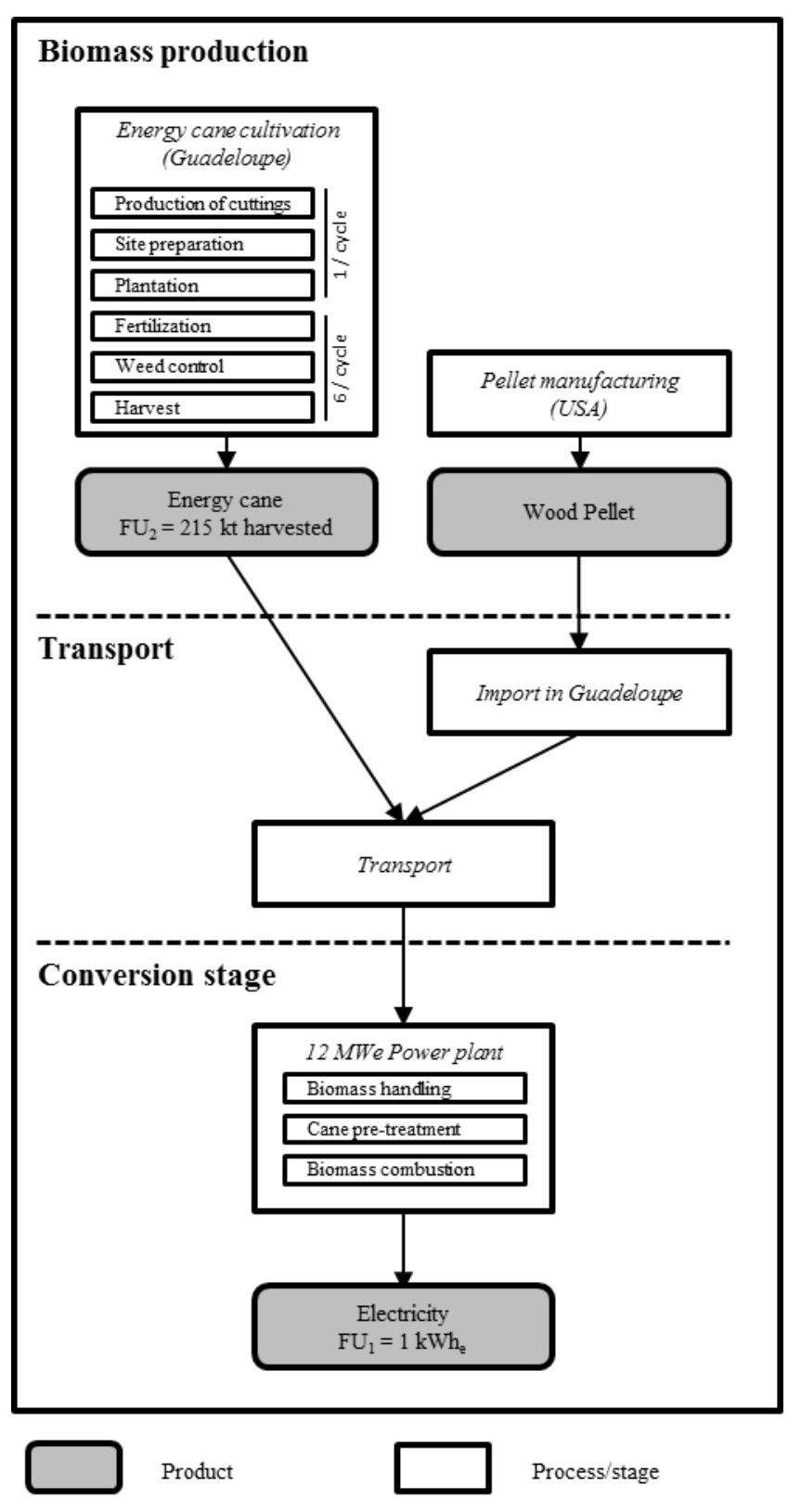

Fig. 2 - Representation of the bioenergy system studied in Guadeloupe. Environmental impacts are calculated for two functional units; $1 \mathrm{kWh}$ of electricity produced from the power-plant $\left(\mathrm{FU}_{1}\right)$ and $215 \mathrm{Mt}$ of energy cane harvested $\left(\mathrm{FU}_{2}\right)$ which corresponds to the amount of biomass needed for provisioning a 12MWe power plant. 


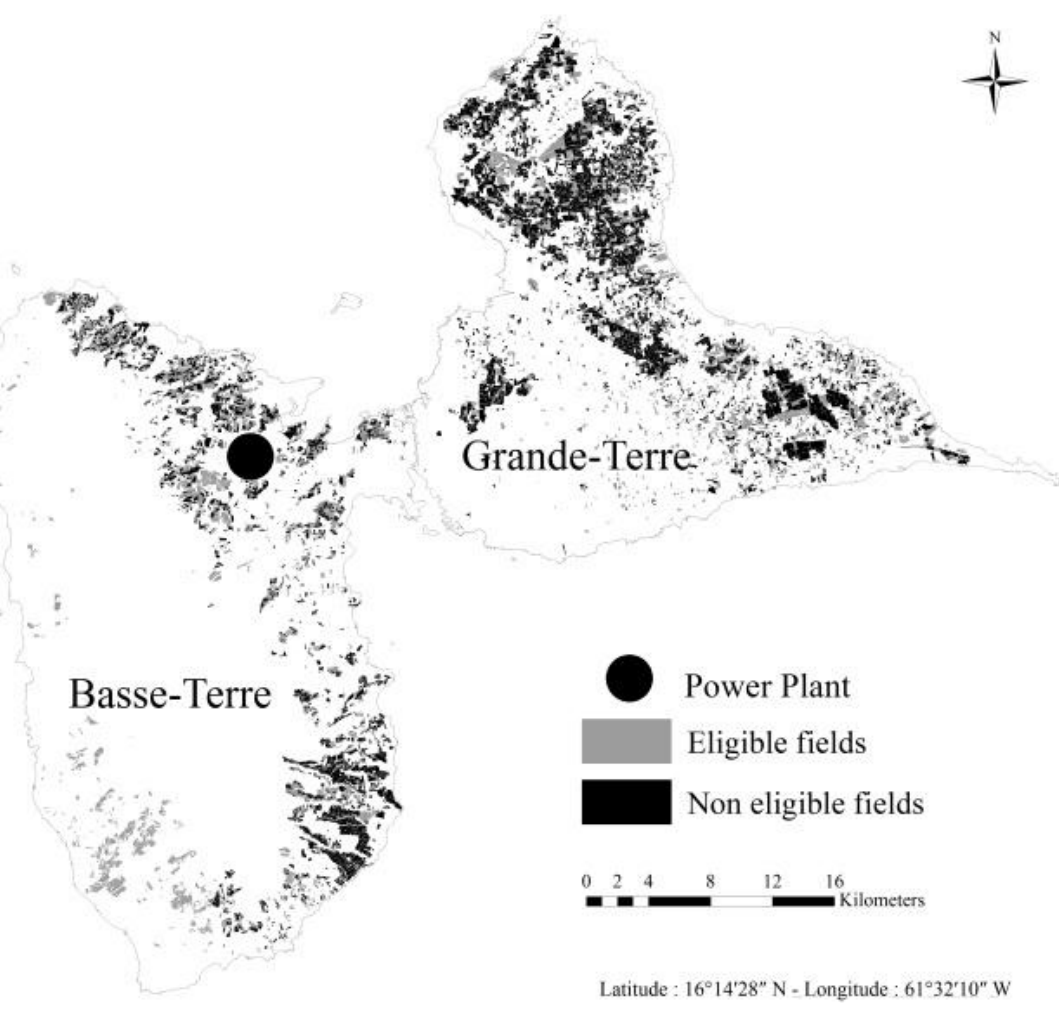

Fig. 3 - Study area for the production and transformation of energy cane in Guadeloupe islands. 


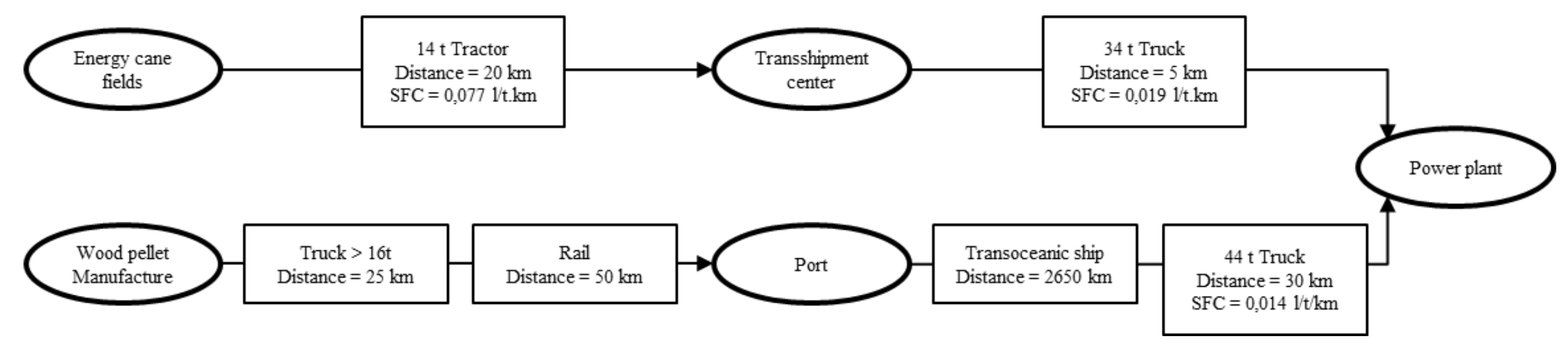

Fig. 4 - Transport steps of the two types of biomass used for the provision of the electricity plant. SFC, Specific Fuel Consumption for transports in Guadeloupe is expressed in liter per ton of biomass transported on 1 kilometer. 


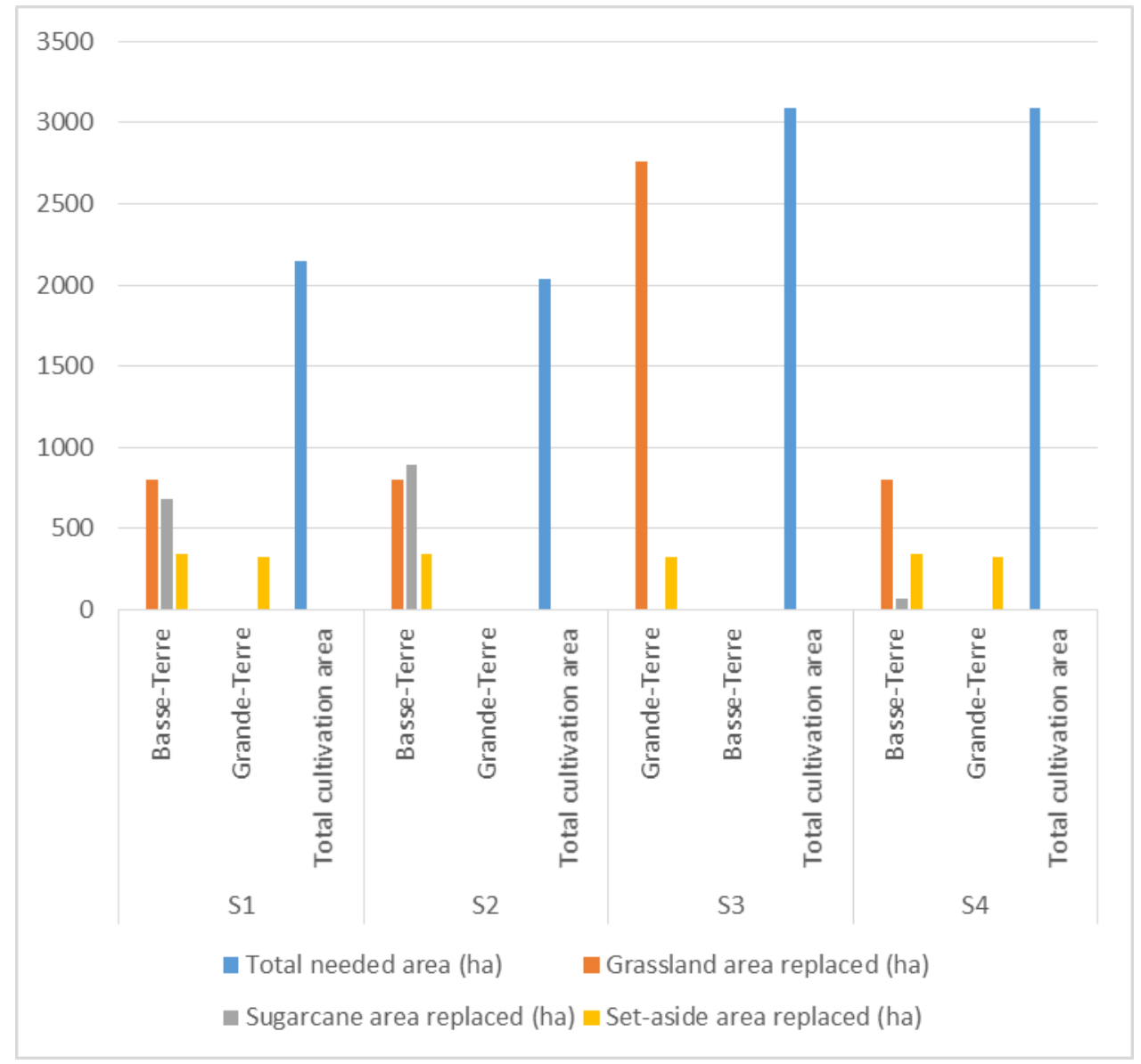

Fig. 5 - Land substitution for energy cane cultivation for the four scenarios in Guadeloupe simulated with the MOSAICA model. 


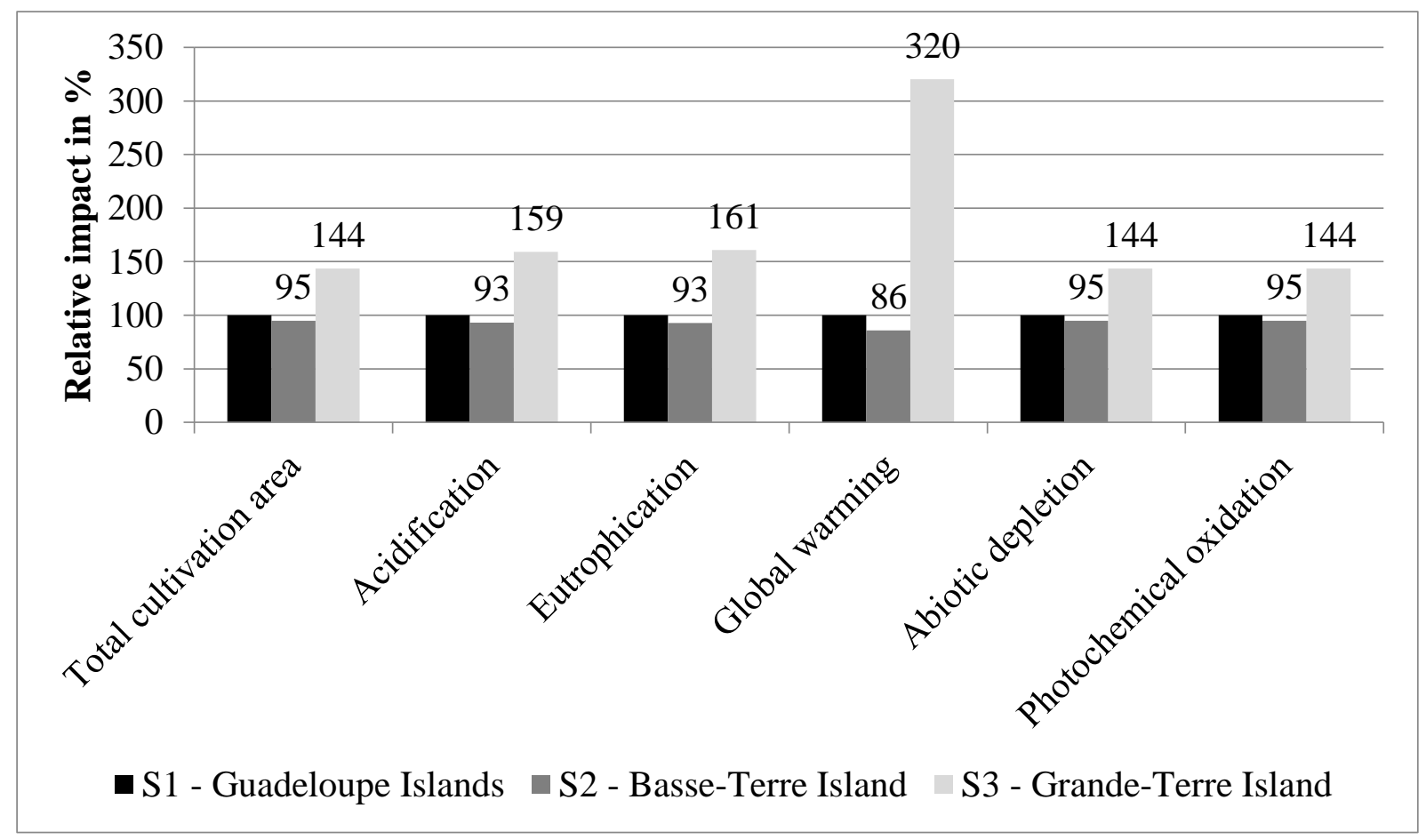

Fig. 6 - Comparison of the impacts of biomass production according to the geographical area, calculated for 215000 tons of energy cane harvested and expressed as relative impacts (base index $\mathrm{S} 1=100$ ). 


\section{Global warming (kg $\mathrm{CO}_{2}$ eq./215 kt energy cane harvested)}

S1

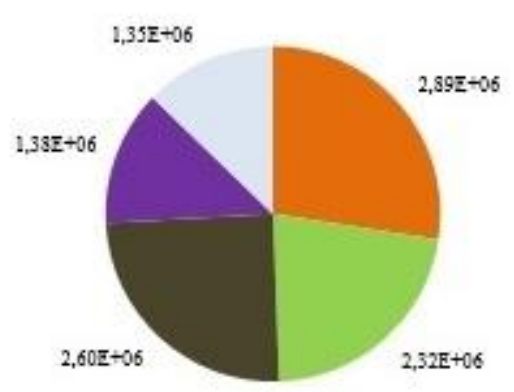

Total : $1.05 \mathrm{E}+07$
S2

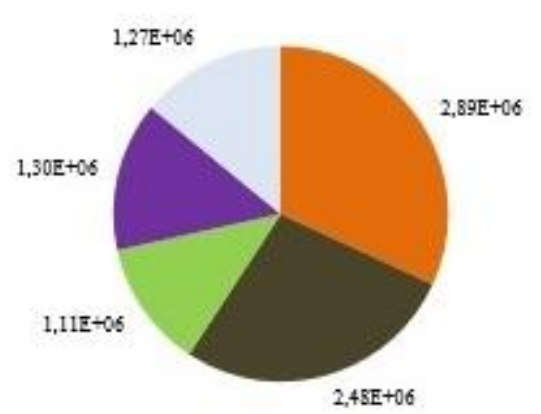

Total : $9.06 \mathrm{E}+06$
S3

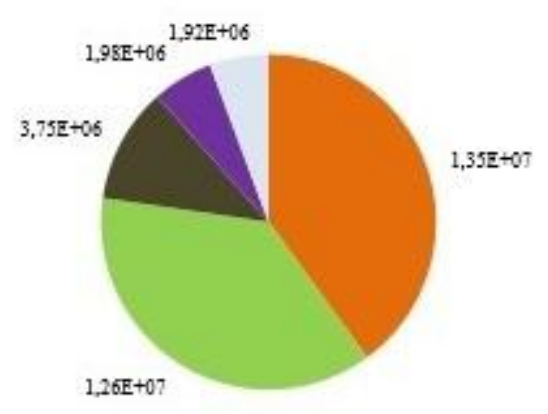

Total : 3.37E +07

Land Use Change $\quad$ Fertiliser field emissions $\quad$ Fertiliser production $\mathbf{w a r v e s t}$ Others

Fig. 7 - Impact distribution of energy cane cultivation for global warming. Biomass production area is located in Guadeloupe (S1), in BasseTerre (S2) or in Grande-Terre islands (S3). 

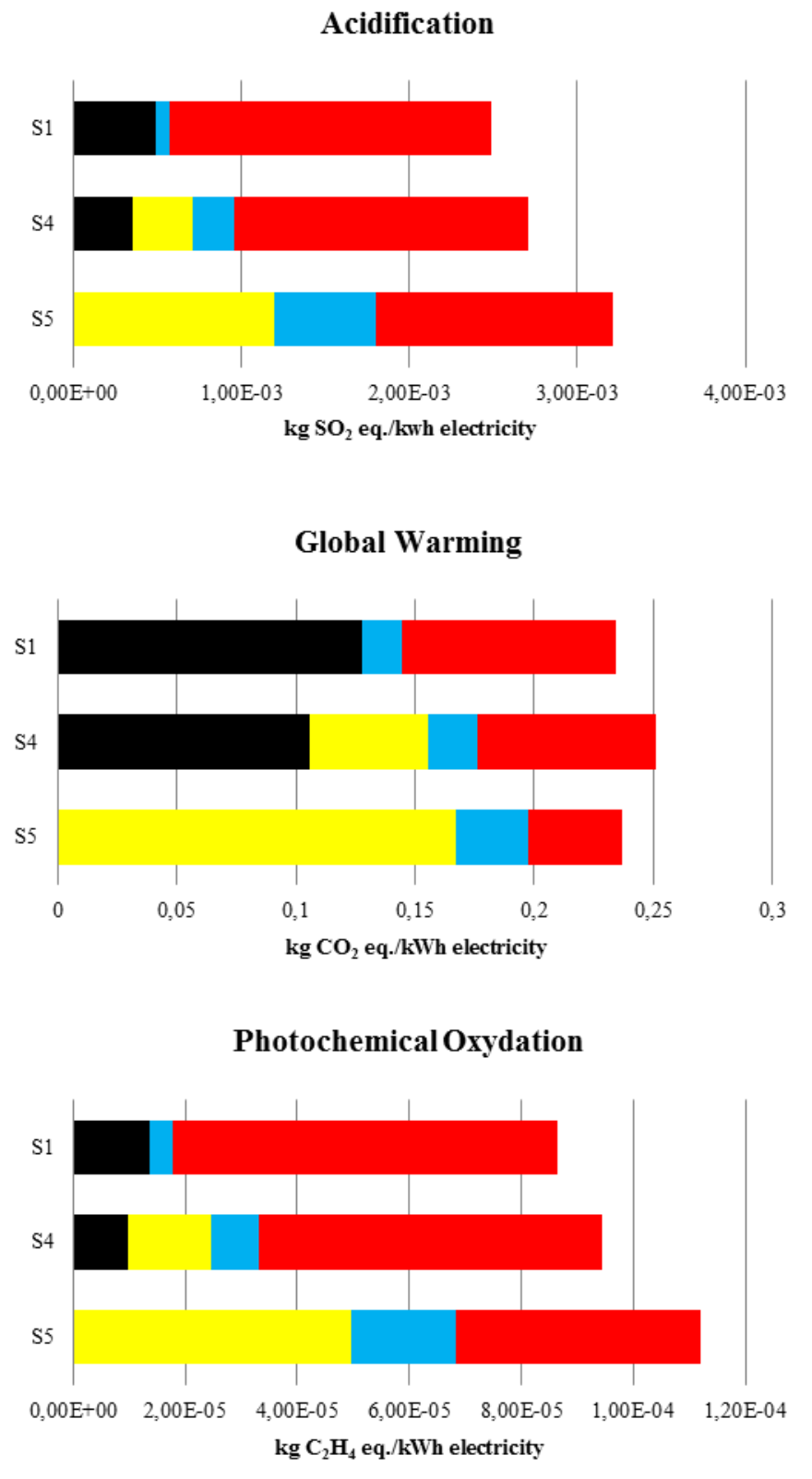

Eutrophication

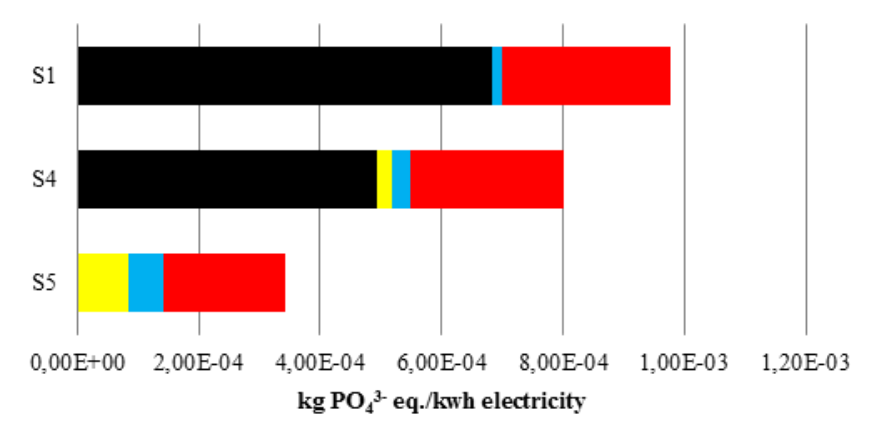

Abiotic Depletion
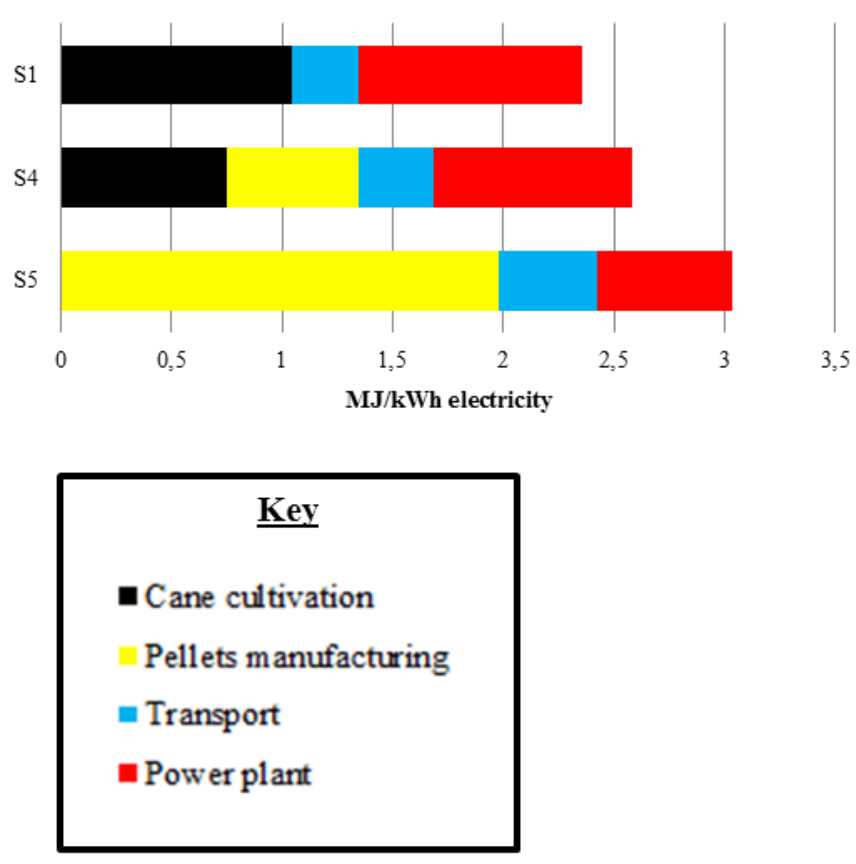

Fig. 8 - Comparison and distribution of impacts among the energy production chain according to the feedstock supply scenarios for acidification, eutrophication, global warming, abiotic depletion and photochemical oxidation. Feedstock is made of $100 \%$ of energy cane in S1, $70 \%$ of energy cane and $30 \%$ of imported wood pellets in S4 and $100 \%$ of imported wood pellets in S5. 
Acidification

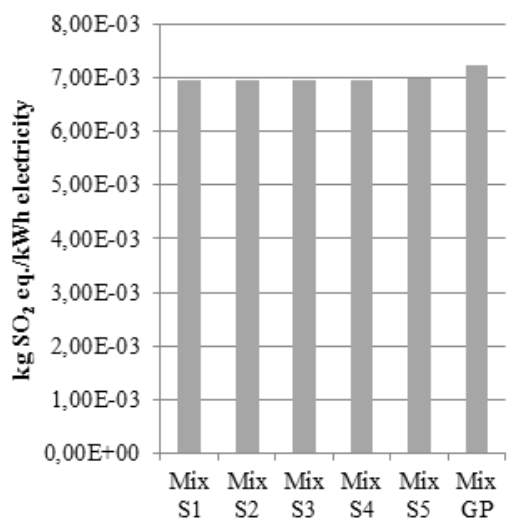

\section{Global Warming}

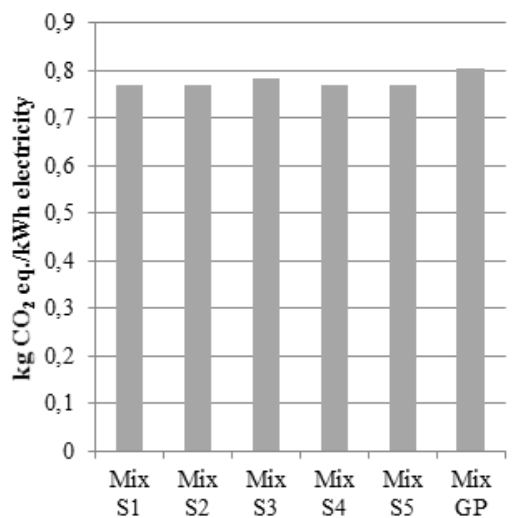

Eutrophication

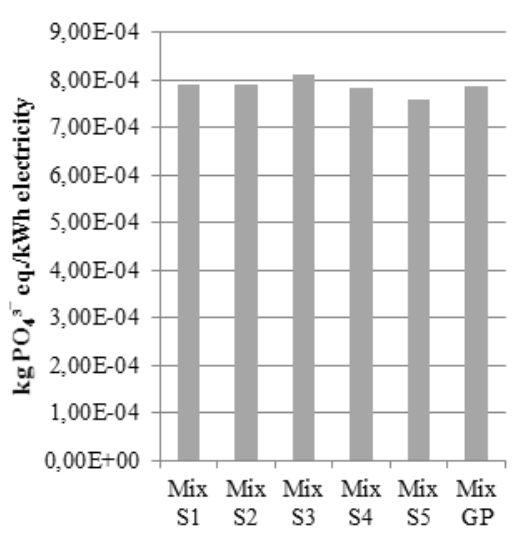

Abiotic Depletion

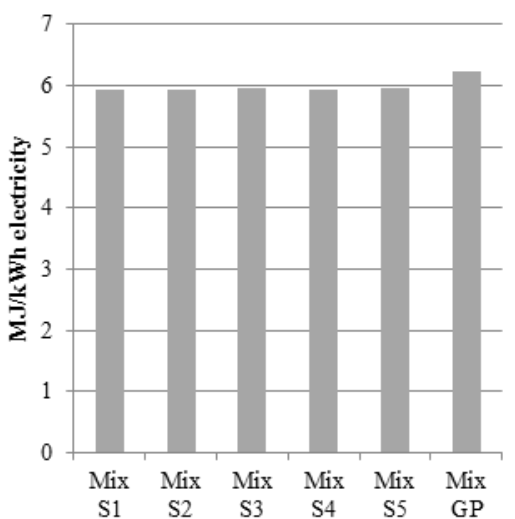

Photochemical Oxidation

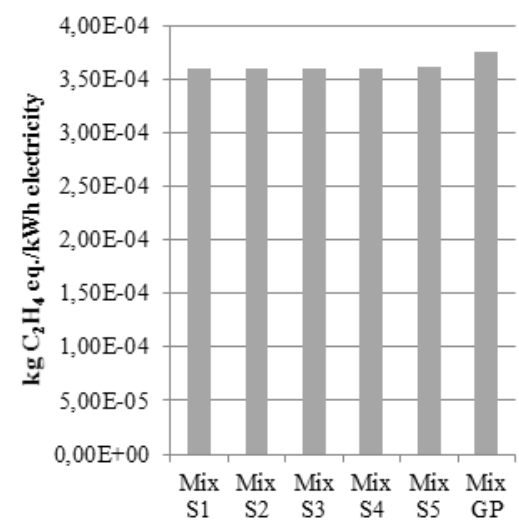

\section{Land Occupation}

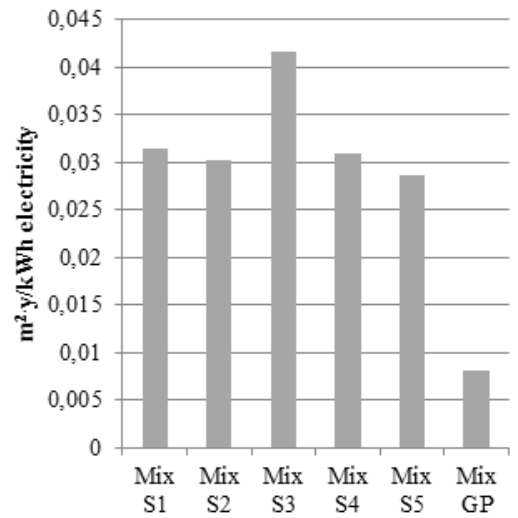

Fig. 9 - Life cycle impact assessment of 1kWh of electricity produced in Guadeloupe from an electricity mix based on $82.5 \%$ of fossil energy (Mix GP) and from alternatives mix where $5 \%$ of energy from oil and hard coal (2,5\% each) are substituted by $5 \%$ of biomass. Mix S1, $100 \%$ of biomass is energy cane cultivated in Guadeloupe; Mix S2, 100\% biomass is energy cane cultivated in Basse-Terre Island, Mix S3, 100\% of biomass is energy cane cultivated in Grande-Terre Island; Mix S4, 30\% biomass is imported wood pellets and 70\% is energy cane cultivated in Guadeloupe; Mix S5, 100\% of biomass is imported wood pellets. 


\section{$\underline{\text { Appendix A. Supplementary data }}$}

\begin{tabular}{|c|c|c|c|c|}
\hline Agricultural operations & $\begin{array}{l}\text { Frequency per } \\
\text { crop cycle }\end{array}$ & Equipment & $\begin{array}{l}\text { Work output } \\
\text { (h/ha) }\end{array}$ & $\begin{array}{l}\text { Fuel consumption } \\
(1 / \mathrm{h})\end{array}$ \\
\hline Soil decompactation & 1 & $\begin{array}{l}\text { Tractor } 110 \mathrm{CV} \text { - Subsoil } \\
\text { plow }\end{array}$ & 2.00 & 22.84 \\
\hline Manuring & 1 & $\begin{array}{l}\text { Tractor } 110 \mathrm{CV} \text { - Solid } \\
\text { manure spreader - } 5 \mathrm{t}\end{array}$ & 1.25 & 17.13 \\
\hline $\begin{array}{l}\text { Tillage } 1-\text { Stubble } \\
\text { ploughing }\end{array}$ & 1 & $\begin{array}{l}\text { Tractor } 150 \mathrm{CV} \text { - Stuble share } \\
4 \mathrm{~m}\end{array}$ & 1.75 & 31.15 \\
\hline Tillage 2 - Ploughing & 1 & Tractor $150 \mathrm{CV}$ - Soc plough & 3.50 & 31.15 \\
\hline $\begin{array}{l}\text { Tillage } 3-\text { Stubble } \\
\text { ploughing }\end{array}$ & 1 & $\begin{array}{l}\text { Tractor } 80 \mathrm{CV} \text { - Stuble share } \\
2.5 \mathrm{~m}\end{array}$ & 1.23 & 12.46 \\
\hline Sowing & 1 & Tractor $110 \mathrm{CV}-$ Row how & 1.15 & 22.84 \\
\hline Seeding & 1 & Cane-loader $60 \mathrm{CV}$ & 3.00 & 16.22 \\
\hline Earthing up & 1 & Tractor $90 \mathrm{CV}$ - Row how & 2.27 & 14.02 \\
\hline Chemical weeding & 12 & $\begin{array}{l}\text { Tractor } 100 \mathrm{CV} \text { - Atomiser } \\
1000 \mathrm{~kg}\end{array}$ & 0.46 & 15.58 \\
\hline Weeding & 6 & $\begin{array}{l}\text { Tractor } 100 \mathrm{CV} \text { - Rotary } \\
\text { mower } 3 \mathrm{~m}\end{array}$ & 1.50 & 15.58 \\
\hline Fertilizing & 6 & $\begin{array}{l}\text { Tractor } 100 \mathrm{CV} \text { - Sprayer } \\
25001\end{array}$ & 1.00 & 15.58 \\
\hline Hoeing & 6 & Tractor $80 \mathrm{CV}$ - Hoeing & 2.30 & 12.86 \\
\hline Harvesting & 6 & Cane harvester $340 \mathrm{CV}$ & 3.00 & 66.63 \\
\hline
\end{tabular}

Table A.1. Description of agricultural operations and equipment for energy cane culture. 


\begin{tabular}{|c|c|c|c|}
\hline & \multirow[t]{2}{*}{ Unit } & \multicolumn{2}{|c|}{ Quantity } \\
\hline & & Basse-Terre & Grande-Terre \\
\hline \multicolumn{4}{|l|}{ Inputs from nature } \\
\hline Land occupation & ha & 1 & 1 \\
\hline $\begin{array}{l}\text { Energy, gross calorific value, in biomass } \\
\text { Other inputs }\end{array}$ & MJ & 450677 & 297738 \\
\hline Cuttings & $\mathrm{kg}$ & 1833.33 & 1833.33 \\
\hline \multicolumn{4}{|l|}{ Agricultural operations } \\
\hline Tillage 1 -Stubble ploughing & $\mathrm{h}$ & 0.2917 & 0.2917 \\
\hline Tillage 2 - Ploughing & $\mathrm{h}$ & 0.5833 & 0.5833 \\
\hline Tillage 3 - stubble ploughing & $\mathrm{h}$ & 0.2050 & 0.2050 \\
\hline Sowing & $\mathrm{h}$ & 0.1917 & 0.1917 \\
\hline Seeding & $\mathrm{h}$ & 0.8167 & 0.8167 \\
\hline Earthing up & $\mathrm{h}$ & 0.3783 & 0.3783 \\
\hline Chemical weeding & $\mathrm{h}$ & 0.9967 & 0.9967 \\
\hline Fertilizing & $\mathrm{h}$ & 1.000 & 1.000 \\
\hline Hoeing & $\mathrm{h}$ & 2.300 & 2.300 \\
\hline Harvesting & $\mathrm{h}$ & 2.850 & 2.850 \\
\hline \multicolumn{4}{|l|}{ Pesticides } \\
\hline Prowl & $\mathrm{kg}$ & 0.2000 & 0.2000 \\
\hline Merlin 75 & $\mathrm{~kg}$ & 0.0166 & 0.0166 \\
\hline Asulox 40 & $\mathrm{~kg}$ & 3.6000 & 3.6000 \\
\hline Dicopur 600 & $\mathrm{~kg}$ & 1.2000 & 1.2000 \\
\hline Glyphosate & $\mathrm{kg}$ & 1.3500 & 1.3500 \\
\hline \multicolumn{4}{|l|}{ Fertilizer } \\
\hline Urea, as $\mathrm{N}$ & $\mathrm{kg}$ & 248 & 248 \\
\hline Triple superphosphate, as $\mathrm{P}_{2} \mathrm{O}_{5}$ & $\mathrm{~kg}$ & 117 & 117 \\
\hline Potassium chloride, as $\mathrm{K}_{2} \mathrm{O}$ & $\mathrm{kg}$ & 280 & 280 \\
\hline \multicolumn{4}{|l|}{ Emissions to air } \\
\hline Dinitrogen monoxide & $\mathrm{kg}$ & 1.8276 & 13.6551 \\
\hline Ammonia & $\mathrm{kg}$ & 0.5204 & 1.9977 \\
\hline Nitrogen oxides & $\mathrm{kg}$ & 0.3838 & 0.4195 \\
\hline Carbon dioxide, land use change & $\mathrm{t}$ & $*$ & $*$ \\
\hline \multicolumn{4}{|l|}{ Emissions to water } \\
\hline Nitrate & $\mathrm{kg}$ & 151.4825 & 151.4825 \\
\hline Phosphate & $\mathrm{kg}$ & 0.0236 & 0.0236 \\
\hline \multicolumn{4}{|l|}{ Emissions to soil } \\
\hline Pendimethalin & $\mathrm{kg}$ & 0.2000 & 0.2000 \\
\hline Isoxaflutole & $\mathrm{kg}$ & 0.0166 & 0.0166 \\
\hline Asulam & $\mathrm{kg}$ & 3.6000 & 3.6000 \\
\hline 2.4-D & $\mathrm{kg}$ & 1.2000 & 1.2000 \\
\hline Glyphosate & $\mathrm{kg}$ & 1.3500 & 1.3500 \\
\hline
\end{tabular}

Table A.2. Primary data inventory for the agricultural stage of energy cane in Guadeloupe Islands (Basse-Terre and Grande Terre). Values are given per ha for an average year over the 6 years culture cycle. 


\begin{tabular}{lc}
\hline Emissions & Emission factors $(\mathrm{g} / \mathrm{kWhe})$ \\
\hline $\mathrm{CO}_{2}$ from biomass & 0.00 \\
$\mathrm{CO}_{2}$ from fossil energy & 1.34 \\
$\mathrm{CO}$ & 0.52 \\
$\mathrm{SO}_{2}$ & 0.52 \\
$\mathrm{NOx}$ & 1.03 \\
Particles & 0.13 \\
\hline
\end{tabular}

Table A.3. Air emissions from boiler operating and biomass (70\% energy cane and 30\% wood pellets) combustion in power plant. 


\begin{tabular}{|c|c|c|c|c|}
\hline & & \multirow{2}{*}{$\begin{array}{c}\text { S1 } \\
\text { Base }\end{array}$} & \multicolumn{2}{|c|}{$\begin{array}{l}\text { Power plant net energy conversion } \\
\text { factor }\end{array}$} \\
\hline & & & $-10 \%$ & $+10 \%$ \\
\hline Acidification & $\mathrm{kg} \mathrm{SO}_{2}$ eq./kWh & $2.48 \mathrm{E}-03$ & $\begin{array}{l}\text { 2.60E-03 } \\
(+4.8 \%)\end{array}$ & $\begin{array}{c}2.39 \mathrm{E}-03 \\
(-3.9 \%)\end{array}$ \\
\hline Eutrophication & $\mathrm{kg} \mathrm{PO}_{4}{ }^{3-}$ eq./kWh & $9.77 \mathrm{E}-04$ & $\begin{array}{l}1.06 \mathrm{E}-03 \\
(+8.8 \%)\end{array}$ & $\begin{array}{c}9.06 \mathrm{E}-04 \\
(-7.3 \%)\end{array}$ \\
\hline Global warming & $\mathrm{kg} \mathrm{CO}_{2}$ eq. $/ \mathrm{kWh}$ & $2.34 \mathrm{E}-01$ & $\begin{array}{l}2.56 \mathrm{E}-01 \\
(+9.2 \%)\end{array}$ & $\begin{array}{c}2.17 \mathrm{E}-01 \\
(-7.6 \%)\end{array}$ \\
\hline Abiotic depletion & $\mathrm{MJ} / \mathrm{kWh}$ & $2.36 \mathrm{E}+00$ & $\begin{array}{r}2.55 \mathrm{E}+00 \\
(+8.2 \%)\end{array}$ & $\begin{array}{c}2.20 \mathrm{E}+00 \\
(-6.8 \%)\end{array}$ \\
\hline Photochemical Oxidation & $\mathrm{kg} \mathrm{C}_{2} \mathrm{H}_{4}$ eq./kWh & $8.65 \mathrm{E}-05$ & $\begin{array}{l}9.12 \mathrm{E}-05 \\
(+5.5 \%)\end{array}$ & $\begin{array}{c}8.26 \mathrm{E}-05 \\
(-4.5 \%)\end{array}$ \\
\hline Land Occupation & $\mathrm{m}^{2}$.year $/ \mathrm{kWh}$ & 4.72E-01 & $\begin{array}{l}5.24 \mathrm{E}-01 \\
(+11.1 \%)\end{array}$ & $\begin{array}{l}\text { 4.29E-01 } \\
(-9.1 \%)\end{array}$ \\
\hline
\end{tabular}

Table A.4. LCA results of the sensitivity analysis with Power plant net energy conversion factor as parameter. Results are expressed per $\mathrm{kWh}$ produced and as percentage of variation of the impact relative to the base scenario. S1, base scenario with $100 \%$ of energy cane in the power plant. 


$\begin{array}{lllll}\text { S1 } & \text { S2 } & \text { S3 } & \text { S4 } & \text { S5 }\end{array}$

\begin{tabular}{lllllll}
\hline Acidification & $\mathrm{kg} \mathrm{SO}_{2}$ eq./UF & $2.48 \mathrm{E}-03$ & $2.45 \mathrm{E}-03$ & $2.77 \mathrm{E}-03$ & $2.71 \mathrm{E}-03$ & $3.21 \mathrm{E}-03$ \\
Eutrophication & $\mathrm{kg} \mathrm{PO}_{4}{ }^{3-}$ eq./UF & $9.77 \mathrm{E}-04$ & $9.28 \mathrm{E}-04$ & $1.39 \mathrm{E}-03$ & $8.01 \mathrm{E}-04$ & $3.41 \mathrm{E}-04$ \\
Global warming & $\mathrm{kg} \mathrm{CO}_{2}$ eq./UF & $2.34 \mathrm{E}-01$ & $2.17 \mathrm{E}-01$ & $5.16 \mathrm{E}-01$ & $2.51 \mathrm{E}-01$ & $2.37 \mathrm{E}-01$ \\
Abiotic depletion & $\mathrm{MJ} / \mathrm{UF}$ & $2.36 \mathrm{E}+00$ & $2.31 \mathrm{E}+00$ & $2.82 \mathrm{E}+00$ & $2.58 \mathrm{E}+00$ & $3.03 \mathrm{E}+00$ \\
Photochemical Oxidation & $\mathrm{kg} \mathrm{C}_{2} \mathrm{H}_{4} \mathrm{eq} . / \mathrm{UF}$ & $8.65 \mathrm{E}-05$ & $8.58 \mathrm{E}-05$ & $9.24 \mathrm{E}-05$ & $9.43 \mathrm{E}-05$ & $1.12 \mathrm{E}-04$ \\
\multirow{2}{*}{$\begin{array}{l}\text { Land Occupation } \\
\text { M }\end{array}$} & $\mathrm{m}^{2}$.year/UF & $4.72 \mathrm{E}-01$ & $4.48 \mathrm{E}-01$ & $6.76 \mathrm{E}-01$ & $4.62 \mathrm{E}-01$ & $4.14 \mathrm{E}-01$ \\
\hline
\end{tabular}

Table A.5. Life cycle impact assessment of $1 \mathrm{kWh}$ of electricity produced from biomass provision scenarios in Guadeloupe. S1, 100\% of energy cane cultivated in Guadeloupe; S2, 100\% of energy cane cultivated in Basse-Terre Island, S3, 100\% of energy cane cultivated in Grande-Terre Island; S4, 30\% of imported wood pellets and 70\% of energy cane cultivated in Guadeloupe; S5, 100\% of imported wood pellets. 